\title{
Genetic variation of the Ananas genus with ornamental potential
}

\author{
Everton Hilo de Souza • Fernanda Vidigal Duarte Souza • \\ Maria Angélica Pereira de Carvalho Costa • Davi Silva Costa Jr • \\ Janay Almeida dos Santos-Serejo • Edson Perito Amorim • \\ Carlos Alberto da Silva Ledo
}

Received: 20 April 2011/ Accepted: 23 September 2011/Published online: 13 October 2011

(C) The Author(s) 2011. This article is published with open access at Springerlink.com

\begin{abstract}
Brazil is one of the main centers of origin of pineapple species presenting the largest genetic variation of the Ananas genus. Embrapa Cassava and Fruits is a Brazilian Agricultural Research Corporation and has an ex-situ collection of 678 accessions of the Ananas genus and some other Bromeliaceae. The use of ornamental pineapple has increased in the last years demanding new varieties, mainly for the external market, due to the originality and colors of its tiny fruits. The main aim of the present study was describing accessions from the pineapple gene bank in order to quantify their genetic variation and identify possible progenitors to be used in breeding programs
\end{abstract}

Everton H. Souza and Fernanda Vidigal Duarte Souza contributed equally to this work.

\section{E. H. de Souza ( $\square)$}

Center of Nuclear Energy in Agriculture, University of São Paulo, Box 96, Piracicaba, SP 13416-005, Brazil e-mail: hilosouza@cena.usp.br

F. V. D. Souza - J. A. dos Santos-Serejo ·

E. P. Amorim - C. A. da Silva Ledo

Embrapa Cassava and Fruits, Brazilian Agricultural

Research Corporation, Cruz das Almas, BA 44380-000, Brazil

M. A. P. de Carvalho Costa - D. S. Costa Jr Center of Agricultural, Environmental and Biological Sciences, Federal University of Recôncavo da Bahia, Cruz das Almas, BA 44380-000, Brazil of ornamental pineapples. Eighty-nine accessions of Ananas comosus var. comosus, A. comosus var. bracteatus (Lindl.) Coppens et Leal, A. comosus var. ananassoides (Baker) Coppens et Leal, A. comosus var. erectifolius (L. B. Smith) Coppens et Leal, A. comosus var. parguasensis (Camargo et L. B. Smith) Coppens et Leal and A. macrodontes Morren were evaluated with 25 morphological descriptors. According to the results, the evaluated accessions were separated into the following categories: landscape plants, cut flower, potted plants, minifruits, foliage and hedge. The genetic distance among accessions was determined using the combined qualitative and quantitative data by the Gower algorithm. The pre-selected accessions presented genetic variation and ornamental potential for different uses. The multicategory analysis formed seven clusters through a classification method based on the average Euclidean distance between all accessions using the cut-point of genetic dissimilarity ( $D d g=0.35$ ). The genotypes $A$. comosus var. erectifolius were selected to be used as landscape plants, cut flower, minifruits and potted plants. Accessions of A. comosus var. bracteatus and A. macrodontes were selected as landscape plants and hedge. The highest variation was observed in A. comosus var. ananassoides genotypes, which presented high potential for use as cut flowers.

Keywords Ananas - Genetic diversity · Morphological descriptors · Ornamental plants . Pineapple $\cdot$ Pre-breeding 


\section{Introduction}

Pineapple species are members of the family of Bromeliaceae, is the sixth most economically exploited tropical fruit in the world. It obtained an output of 18.4 million tonnes in 2009 (FAO 2011).

Potential uses have been explored for species of the genus Ananas, including the production of fibers for the manufacture of rustic material, such as ropes and fabric; the use in the automotive industry as a source of nanocellulose plastic, more resistant to heat, gasoline and water and he envisions using it for dashboards, bumpers and body panels (Mohanty et al. 2000; Zah et al. 2007; Leão et al. 2009); manufacture of paper (Marques et al. 2007); proteolytic enzymes (Maurer 2001) and secondary metabolites with antioxidant and biological activities of great value for the pharmaceutical, cosmetic and food industry (Harvey 2000; Manetti et al. 2009); besides its great ornamental potential (Duval et al. 2001a; Souza et al. 2006, 2007, 2009; Coppens D'Eeckenbrugge and Duval 2009; Sanewski 2009).

Ornamental use has increased in recent years and generating demand, due to the exotic and colorful aspect of the small pineapple fruits (Souza et al. 2009).

Searching for new varieties has increased recently, since the trade of ornamental pineapples is limited to two varieties, namely, one genotype of $A$. comosus var. erectifolius and another of $A$. comosus var. bracteatus.

Brazil is the center of origin and genetic diversity of the genus and Embrapa Cassava and Fruits, a Brazilian Agricultural Research Corporation, maintains a Active Germplasm Bank (AGB) located in Cruz das Almas city, Bahia, Brazil, with 678 accessions, distributed into botanic species and varieties of the genus Ananas and other Bromeliaceae (Souza et al. 2009).

This collection has potential to identify and generate new varieties, mainly considering the significant genetic variation of the genus. Studies on this variation may provide the support for a genetic breeding program aiming to generate new ornamental hybrids of pineapple.

Therefore, the characterization of these accessions is crucial to identify the ornamental potential of the collection. The studies on the identification, characterization and evaluation of pineapple germplasm provide important data on the accessions evaluated, highlighting the relevance of maintenance an active germplasm bank, in which the genetic variation of certain species can be used for different purposes, including ornamentation.

Previous studies by Souza et al. (2006, 2007, 2009) presented the characteristics that must be considered to identify and select ornamental pineapple plants, including plant size, length and color of the leaves and length, diameter, morphology and color of syncarps. Based on that study, 89 accessions with ornamental potential use were selected.

The identification of a certain accession with potential to be used as potted plant, or for landscape plants, foliage, inflorescence cutting or even as ornamental minifruits depends on the set of characteristics related to each of these categories. Besides, these accessions may be potential parents in breeding programs for the generation of hybrids with the desired characteristics, even without presenting all the desirable characteristics for a certain use.

Therefore, this work aimed at describing accessions from the pineapple active germplasm bank with ornamental potential. Also, the purpose was to estimate their genetic variation and classification into the different categories of ornamental use, identifying possible parents for genetic breeding targeting ornamental hybrids.

\section{Materials and methods}

This study was conducted at the pineapple Active Germplasm Bank (pineapple AGB) of the Embrapa Cassava \& Fruits, located at $12^{\circ} 40^{\prime}$ south latitude and $39^{\circ} 06^{\prime}$ west longitude, in the municipality of Cruz das Almas, Bahia, Brazil.

According to the Köppen classification, the climate in Cruz das Almas is a transition between the Am and Aw zones, with average annual rainfall of $1.143 \mathrm{~mm}$, average temperature of $24.28^{\circ} \mathrm{C}$ and relative humidity of $60.47 \%$. The soil of the experimental area is a typical dystrophic Yellow Latosol, A moderate, sandy clay loam texture, kaolinite, hypoferric, transition zone between subperennial and semideciduous rainforest, with slope of $0-3 \%$.

A total of 89 accessions of pineapple species, varieties and inter-varieties hybrids with ornamental potential were previously selected for this study and are presented in Table 1 . The accessions were planted in $1.0 \times 0.8 \mathrm{~m}$ plots, with four replications, each corresponding to one plant. 
Table 1 Accessions identified and characterized in the pineapple AGB of the Embrapa Cassava \& Fruits which hold ornamental potential and their respective species and provenance

\begin{tabular}{|c|c|c|c|c|c|}
\hline Number & Name of the accession & Proven. & Number & Name of the accession & Proven. \\
\hline \multicolumn{6}{|c|}{ Ananas comosus var. comosus } \\
\hline AGB 16 & Roxo de Tefé & $\mathrm{BR} / \mathrm{AM}$ & AGB 382 & LBB-605 & $\mathrm{BR} / \mathrm{MA}$ \\
\hline AGB 28 & Branco & $\mathrm{BR} / \mathrm{AM}$ & AGB 458 & LBB-1408 & $\mathrm{BR} / \mathrm{AC}$ \\
\hline AGB 101 & FRF-747 & $\mathrm{BR} / \mathrm{AP}$ & AGB 511 & G-42 & FG \\
\hline AGB 137 & Arroba Tarauacá & $\mathrm{BR} / \mathrm{AC}$ & AGB 693 & FRF-1015 & BR/AM \\
\hline AGB 380 & LBB-608 & BR/MA & AGB 772 & GF-492 & FG \\
\hline \multicolumn{6}{|c|}{ Ananas comosus var. erectifolius } \\
\hline AGB 739 & Curauá Roxo & $\mathrm{BR} / \mathrm{PA}$ & AGB 804 & FFR-1387 & $\mathrm{BR} / \mathrm{RN}$ \\
\hline AGB 750 & FRF-1392 & $\mathrm{BR} / \mathrm{CE}$ & & & \\
\hline \multicolumn{6}{|c|}{ Ananas comosus var. ananassoides } \\
\hline AGB 25 & Ananaí & $\mathrm{BR} / \mathrm{MT}$ & AGB 385 & LBB-540 & $\mathrm{BR} / \mathrm{GO}$ \\
\hline AGB 174 & FRF-52 (A. do Índio) & $\mathrm{BR} / \mathrm{DF}$ & AGB 464 & LBB-1427 & $\mathrm{BR} / \mathrm{MT}$ \\
\hline AGB 198 & FRF-249 & $\mathrm{BR} / \mathrm{RO}$ & AGB 465 & LBB-1446 & $\mathrm{BR} / \mathrm{MT}$ \\
\hline AGB 207 & FRF-224 & $\mathrm{BR} / \mathrm{RO}$ & AGB 469 & LBB-1437 & $\mathrm{BR} / \mathrm{MT}$ \\
\hline AGB 208 & FRF-221 & $\mathrm{BR} / \mathrm{RO}$ & AGB 470 & LBB-1438 & $\mathrm{BR} / \mathrm{MT}$ \\
\hline AGB 229 & FRF-367 & $\mathrm{BR} / \mathrm{MS}$ & AGB 471 & LBB-1442 & $\mathrm{BR} / \mathrm{MT}$ \\
\hline AGB 230 & FRF-372 & $\mathrm{BR} / \mathrm{MS}$ & AGB 472 & LBB-1439 & $\mathrm{BR} / \mathrm{MT}$ \\
\hline AGB 232 & FRF-393 & $\mathrm{BR} / \mathrm{MT}$ & AGB 475 & LBB-1447 & $\mathrm{BR} / \mathrm{MT}$ \\
\hline AGB 270 & LC-7241 & $\mathrm{BR} / \mathrm{MT}$ & AGB 477 & LBB-1440 & $\mathrm{BR} / \mathrm{MT}$ \\
\hline AGB 315 & D C G-876 & $\mathrm{BR} / \mathrm{DF}$ & AGB 479 & LBB-1448 & $\mathrm{BR} / \mathrm{MT}$ \\
\hline AGB 323 & GHAV e JMTM-11 & $\mathrm{BR} / \mathrm{MT}$ & AGB 487 & LBB-1455 & $\mathrm{BR} / \mathrm{MT}$ \\
\hline AGB 324 & Valls 9385 & $\mathrm{BR} / \mathrm{MT}$ & AGB 523 & G-35 & FG \\
\hline AGB 325 & ARM-955 & $\mathrm{BR} / \mathrm{MT}$ & AGB 526 & G-44 & FG \\
\hline AGB 330 & FRF-667 & $\mathrm{BR} / \mathrm{PA}$ & AGB 703 & CI-33 & $\mathrm{FG}$ \\
\hline AGB 378 & LBB-639 & $\mathrm{BR} / \mathrm{PI}$ & & & \\
\hline \multicolumn{6}{|c|}{ Ananas comosus var. parguasensis } \\
\hline AGB 211 & FRF-755 & BR/AP & AGB 391 & FRF-813 & BR/AP \\
\hline AGB 327 & FRF-691 & $\mathrm{BR} / \mathrm{PA}$ & AGB 404 & FRF-724 & BR/AP \\
\hline AGB 337 & FRF-812 & BR/AP & AGB 775 & GF-491 & FG \\
\hline AGB 388 & FRF-756 & BR/AP & & & \\
\hline \multicolumn{6}{|c|}{ Ananas comosus var. bracteatus } \\
\hline AGB 2 & Ananás São Bento & $\mathrm{BR} / \mathrm{SP}$ & AGB 128 & FRF-32 & $\mathrm{BR} / \mathrm{GO}$ \\
\hline AGB 3 & Ananás Verm. do Mato & $\mathrm{BR} / \mathrm{SP}$ & AGB 210 & FRF-1217 & $\mathrm{BR} / \mathrm{PR}$ \\
\hline AGB 17 & Ananás tricolor & $\mathrm{BR} / \mathrm{SP}$ & AGB 408 & FRF-1203 & $\mathrm{BR} / \mathrm{RS}$ \\
\hline AGB 20 & Ananás Branco do Mato & $\mathrm{BR} / \mathrm{SP}$ & AGB 495 & FRF-1209 & $\mathrm{BR} / \mathrm{RS}$ \\
\hline AGB 35 & Ananás Santo Amaro & $\mathrm{BR} / \mathrm{BA}$ & AGB 510 & FRF-1261 & $\mathrm{BR} / \mathrm{SP}$ \\
\hline AGB 45 & Ananás Minas Gerais & $\mathrm{BR} / \mathrm{MG}$ & AGB 543 & FRF-1213 & $\mathrm{BR} / \mathrm{RS}$ \\
\hline AGB 47 & Selvagem 5 & $\mathrm{BR} / \mathrm{RS}$ & AGB 584 & FRF-1214 & $\mathrm{BR} / \mathrm{SC}$ \\
\hline AGB 56 & BGA-12 & $\mathrm{BR} / \mathrm{BA}$ & AGB 663 & FRF-1419 & $\mathrm{BR} / \mathrm{MG}$ \\
\hline AGB 97 & Silvestre 166 & $\mathrm{BR} / \mathrm{DF}$ & AGB 690 & FRF-1212 & $\mathrm{BR} / \mathrm{RS}$ \\
\hline AGB 110 & FRF-414 & $\mathrm{BR} / \mathrm{ES}$ & AGB 692 & FRF-1136 & $\mathrm{BR} / \mathrm{SP}$ \\
\hline AGB 119 & FRF-16A & $\mathrm{BR} / \mathrm{PR}$ & AGB 776 & BR-725 & FG \\
\hline AGB 123 & FRF-19 & $\mathrm{BR} / \mathrm{GO}$ & AGB 808 & FRF-1393 & $\mathrm{BR} / \mathrm{CE}$ \\
\hline AGB 126 & FRF-22 & $\mathrm{BR} / \mathrm{GO}$ & & & \\
\hline
\end{tabular}


Table 1 continued

\begin{tabular}{|c|c|c|c|c|c|}
\hline Number & Name of the accession & Proven. & Number & Name of the accession & Proven. \\
\hline \multicolumn{6}{|c|}{ Ananas macrodontes } \\
\hline AGB 81 & Silvestre 25 & $\mathrm{BR} / \mathrm{DF}$ & AGB 299 & FRF-327 & $\mathrm{BR} / \mathrm{MS}$ \\
\hline AGB 83 & I-26 803 & $\mathrm{BR} / \mathrm{DF}$ & AGB 719 & FRF-1239 & $\mathrm{BR} / \mathrm{BA}$ \\
\hline \multicolumn{6}{|l|}{ Hybrids } \\
\hline AGB 18 & Pseudananas $\times$ Rondon & $\mathrm{BR} / \mathrm{SP}$ & AGB 148 & S. Cay. $\times$ Ananai & $\mathrm{BR} / \mathrm{BA}$ \\
\hline AGB 146 & A. S. Bento $\times$ Loc. de Tefé & $\mathrm{BR} / \mathrm{BA}$ & AGB 152 & S. Cay. $\times$ Ananás S. Bento & $\mathrm{BR} / \mathrm{BA}$ \\
\hline \multicolumn{6}{|l|}{ Ananas sp. } \\
\hline AGB 195 & GPS-389 & $\mathrm{BR} / \mathrm{AP}$ & AGB 393 & FRF-814 & $\mathrm{BR} / \mathrm{AP}$ \\
\hline AGB 197 & FRF-202 & $\mathrm{BR} / \mathrm{RO}$ & AGB 396 & FRF-818 & $\mathrm{BR} / \mathrm{AP}$ \\
\hline AGB 351 & FRF-719 & $\mathrm{BR} / \mathrm{PA}$ & AGB 507 & G-69 & FG \\
\hline AGB 377 & LBB-550 & $\mathrm{BR} / \mathrm{GO}$ & & & \\
\hline
\end{tabular}

$B R$ Brazil/States, $F G$ French Guiana. Brazilian states: $A C$ Acre, $A P$ Amapá, $A M$ Amazonas, $B A$ Bahia, $C E$ Ceará, $D F$ Distrito Federal, ES Espírito Santo, GO Goiás, $M A$ Maranhão, $M T$ Mato Grosso, $M S$ Mato Grosso do Sul, $M G$ Minas Gerais, $P A$ Pará, $P R$ Paraná, PI Piauí, $R O$ Rondônia, $R N$ Rio Grande do Norte, $R S$ Rio Grande do Sul, SC Santa Catarina, SP São Paulo

Twenty-five morphological descriptors were used. Eleven of them were quantitative and fourteen, qualitative. The list of the descriptors can be found in "International Board for Plant Genetic Resources" (IBPGR 1991).

The following characteristics are considered for the classification of accessions into use categories:

Potted plants plant height lower than $65.00 \mathrm{~cm}$, canopy diameter narrower than $80.00 \mathrm{~cm}$, leaf length less than $60.00 \mathrm{~cm}$, crown/syncarp ratio close to 1 , syncarp length less than $5.00 \mathrm{~cm}$, syncarp diameter less than $3.00 \mathrm{~cm}$, crown length less than $5.00 \mathrm{~cm}$, peduncle length less than $30.00 \mathrm{~cm}$ and absence of spines;

Cut flower crown/syncarp ratio close to 1, syncarp length less than $8.00 \mathrm{~cm}$ and syncarp diameter less than $6.00 \mathrm{~cm}$, peduncle length exceeding $40.00 \mathrm{~cm}$, peduncle diameter less than $1.50 \mathrm{~cm}$ and crown length less than $7.00 \mathrm{~cm}$;

Minifruits syncarp length less than $5.00 \mathrm{~cm}$, crown/ syncarp ratio close to 1 and crown length less than $4.50 \mathrm{~cm}$;

Landscape plants wide category that includes potted plants, cut flower and minifruits. An important characteristic of this category is the formation of clumps, which can be observed in the tillering capacity of the material evaluated.
Foliage leaf length exceeding $1.00 \mathrm{~m}$, leaf width exceeding $5.00 \mathrm{~cm}$, presence of variegation (desirable, but not mandatory), intense color and absence of spines;

Hedge plant height exceeding $80.00 \mathrm{~cm}$, formation of clumps, leaf length exceeding $80.00 \mathrm{~cm}$, leaf width exceeding $5.00 \mathrm{~cm}$ and presence of spines.

Analyses of variance were carried out and the following descriptive statistics were calculated: average, maximum value, minimum value, variation coefficient, $F$ test and average square. A completely randomized experimental design was used, the averages were compared by the Scott-Knott test at $1 \%$ probability using the statistical SAS software system (SAS Institute 2004).

The Singh criterion (1981) was employed to calculate the relative contribution of each quantitative variable, based on Mahalanobis distance, and the analysis was carried out by the Genes software system (Cruz and Regazzi 1997).

A joint analysis of the qualitative and quantitative data was carried out to determine the genetic distance based on the Gower algorithm (1971).

The hierarchical clusterings of the accessions were achieved by the UPGMA methods (Unweighted PairGroup Method Using an Arithmetic Average) based on the average Euclidean distance between all the accessions. The validation of the clusterings was 
determined by the cophenetic correlation coefficient (r) (Sokal and Rohlf 1962).

The statistical software system (R Development Core TeaM. 2006) was used for the analyses of genetic distance, hierarchical clusterings and cophenetic correlation. The cophenetic correlation was calculated by the $t$ and Mantel tests (10,000 permutations). The dendrogram was generated based on the distance matrix by the MEGA 4 software system (Tamura et al. 2007).

\section{Results and discussion}

The application of morphological descriptors to characterize pre-selected accessions of pineapple trees revealed the wide variation of the pineapple germplasm active bank and allowed the identification of accessions with great ornamental potential for different uses, aggregating value to the germplasm preserved (Table 2).

The Singh method (1981) was used to assess the relative importance of the 11 quantitative descriptors. It was also determined, by this method, that four of them provided $98.59 \%$ of the genetic divergence, while seven of them provided only $1.41 \%$. Canopy diameter was the variable with the highest contribution, $53.31 \%$, followed by plant height $(19.57 \%)$, leaf length (15.28\%) and peduncle length (10.43\%). These results indicate the existence of significant genetic variation for these characters in the genotypes evaluated. In general, the length and diameter of the fruit, length and diameter of the inflorescence, crown length, leaf width and peduncle diameter did not contribute to explain the variation observed among the genotypes (Table 3).

The multi-category analysis carried out with the 89 accessions allowed the formation of seven groups (Fig. 1) by the UPGMA clustering method, based on the average Euclidean distance, using the average genetic dissimilarity as the cutting point ( $D d g=$ $0.35)$.

The cophenetic correlation coefficient of the dendrogram (r $=0.81, P<0.0001,10,000$ permutations) revealed good adjustment between the graphic representation of the distances and its original matrix (Rohlf and Fisher 1968).

The group G1 is formed by only one accession of A. comosus var. comosus called 'Arroba Tarauacá', which was selected mainly because of its great height and the purplish color of its leaves and fruits. Its leaves present average length of $126.50 \mathrm{~cm}$ and width of $8.15 \mathrm{~cm}$, its habit is decumbent and its fruits are used for food (Table 4). This accession, although presenting some interesting characteristics, was not recommended as a parent, mainly due to the size of its fruit (Fig. 2a).

The accessions of A. comosus var. comosus are known as pineapple, ananás and nanas and are $65 \%$ of all accessions of the AGB of pineapple of the Embrapa Cassava \& Fruits. This variety presented the highest variation among the accessions evaluated, showed in Fig. 1, in which the variety was identified to form part of different groups. Duval et al. (2000, 2001b) report high genetic variation for this variety, especially in the Western Amazon and Eastern Guiana.

Some accessions accessions that form part of the bank were included in this work due to their attractive colors and relevant characteristics for ornamental purposes. They are mainly used in landscape plants and/or foliage. Out of the 411 accessions that form the bank, only 10 were selected, including the accession Roxo de Tefé (AGB 16), because of its long $(61.33 \mathrm{~cm})$ and wide $(4.07 \mathrm{~cm})$ leaves, reddish color and the large distribution of anthocyanin (Table 4; Fig. 2b). The accession Branco (AGB 28) also stood out, with its olive-green inflorescence, which is very different from ordinary pineapples (Fig. 2c), good development, with $7.15 \mathrm{~cm}$ in length and $4.95 \mathrm{~cm}$ in diameter, open habit and well formed syncarp, whose average length is $8.40 \mathrm{~cm}$ and diameter, $5.95 \mathrm{~cm}$ (Table 5; Fig. 2d).

All accessions of A. comosus var. erectifolius formed the group G2 better known as curaguá, carauá, curaná, kulaiwat, coma-pitte, pitte, lucidus and curauá (Coppens D'Eeckenbrugge and Duval 2009). The last two names are the most commonly used in Brazil.

No significant differences were observed for the three accessions evaluated, with all plants studied have erect habit, a characteristic that gives name to the variety, smooth and purplish leaves with average length of $65.00 \mathrm{~cm}$ and width of $3.50 \mathrm{~cm}$ (Table 4). The peduncle is long, straight, without deformities, with approximately $40.00 \mathrm{~cm}$ in length and $0.80 \mathrm{~cm}$ in diameter (Table 2). Due to these characteristics, the $A$. comosus var. erectifolius has already been used and marketed as cut flower (Brainer and Oliveira 2007). The inflorescence has small and smooth floral bracts 
Table 2 Descriptive statistics for 11 descriptors of ornamental pineapple trees, in different botanic varieties

\begin{tabular}{|c|c|c|c|c|c|c|c|}
\hline & $\mathrm{N}$ & HEI (cm) & CAN (cm) & LLE (cm) & LWI (cm) & LPE $(\mathrm{cm})$ & $\mathrm{DPE}(\mathrm{cm})$ \\
\hline $\begin{array}{r}\text { Ananas comosus } \\
\text { var. bracteatus }\end{array}$ & $25(100)$ & $93.76 \pm 13.16 \mathrm{a}$ & $151.70 \pm 15.06 \mathrm{a}$ & $94.68 \pm 9.59 \mathrm{a}$ & $4.58 \pm 0.41 \mathrm{a}$ & $25.31 \pm 4.92 b$ & $1.83 \pm 0.32 \mathrm{a}$ \\
\hline $\begin{array}{l}\text { A. comosus var. } \\
\text { erectifolius }\end{array}$ & $3(12)$ & $77.31 \pm 7.88 b$ & $80.19 \pm 8.89 b$ & $64.33 \pm 16.21 b$ & $3.46 \pm 3.46 b$ & $39.64 \pm 1.92 \mathrm{a}$ & $0.83 \pm 0.16 b$ \\
\hline $\begin{array}{l}\text { A. comosus var. } \\
\text { ananassoides }\end{array}$ & $29(116)$ & $64.90 \pm 16.58 b$ & $106.01 \pm 26.65 b$ & $72.05 \pm 17.72 b$ & $2.88 \pm 0.77 b$ & $49.83 \pm 16.38 \mathrm{a}$ & $0.85 \pm 0.34 \mathrm{~b}$ \\
\hline $\begin{array}{l}\text { A. comosus var. } \\
\text { parguasensis }\end{array}$ & $7(28)$ & $62.50 \pm 15.33 b$ & $102.56 \pm 20.92 b$ & $70.32 \pm 9.66 b$ & $4.03 \pm 0.75 \mathrm{a}$ & $28.77 \pm 9.08 b$ & $1.17 \pm 0.22 b$ \\
\hline $\begin{array}{l}\text { A. comosus var. } \\
\text { comosus }\end{array}$ & $10(40)$ & $76.12 \pm 18.97 b$ & $125.92 \pm 47.22 \mathrm{a}$ & $84.92 \pm 19.87 a$ & $4.82 \pm 1.63 \mathrm{a}$ & $28.24 \pm 11.15 b$ & $2.00 \pm 0.45 a$ \\
\hline Ananas sp. & $7(28)$ & $63.76 \pm 16.71 b$ & $98.98 \pm 21.46 b$ & $73.86 \pm 21.84 b$ & $3.74 \pm 0.75 b$ & $35.05 \pm 8.97 \mathrm{~b}$ & $1.20 \pm 0.67 b$ \\
\hline Hybrids & $4(16)$ & $70.52 \pm 18.86 b$ & $123.44 \pm 7.52 \mathrm{a}$ & $81.54 \pm 13.34 \mathrm{a}$ & $4.08 \pm 0.55 a$ & $24.69 \pm 12.49 b$ & $1.63 \pm 0.22 \mathrm{a}$ \\
\hline A. macrodontes & $4(16)$ & $74.50 \pm 1.73 b$ & $138.64 \pm 8.43 \mathrm{a}$ & $85.83 \pm 9.61 \mathrm{a}$ & $3.97 \pm 0.47 \mathrm{a}$ & $28.06 \pm 0.77 b$ & $2.05 \pm 0.53 \mathrm{a}$ \\
\hline Mean & & 75.09 & 121.63 & 80.64 & 3.85 & 35.24 & 1.39 \\
\hline $\mathrm{CV}(\%)$ & & 20.60 & 20.70 & 19.15 & 21.05 & 32.56 & 27.04 \\
\hline $\mathrm{Fc}$ & & $8.26 * *$ & $9.54 * *$ & $5.53 * *$ & $11.23 * *$ & $10.99 * *$ & $20.47 * *$ \\
\hline AS & & 1977.50 & 6046.39 & 1318.44 & 7.39 & 1447.56 & 2.92 \\
\hline & & $\mathrm{N}$ & LIN (cm) & DIN (cm) & LSY (cm) & DSY (cm) & $\operatorname{LCR}(\mathrm{cm})$ \\
\hline \multicolumn{2}{|c|}{ Ananas comosus var. bracteatus } & $25(100)$ & $7.21 \pm 1.80 \mathrm{a}$ & $5.01 \pm$ & $9.00 \pm$ & $6.23 \pm 0.90 \mathrm{a}$ & $4.79 \pm 1.29 a$ \\
\hline \multicolumn{2}{|c|}{ A. comosus var. erectifolius } & $3(12)$ & $3.54 \pm 1.05 b$ & $1.82 \pm 0.57 \mathrm{~d}$ & $4.81 \pm 0.77 b$ & $3.63 \pm 1.07 \mathrm{~b}$ & $2.96 \pm 0.27 \mathrm{a}$ \\
\hline \multicolumn{2}{|c|}{ A. comosus var. ananassoides } & 29 (116) & $3.58 \pm 1.20 \mathrm{~b}$ & $2.40 \pm 0.72 \mathrm{~d}$ & $5.15 \pm 1.65 b$ & $3.54 \pm 0.97 b$ & $2.15 \pm 1.38 b$ \\
\hline \multicolumn{2}{|c|}{ A. comosus var. parguasensis } & $7(28)$ & $4.53 \pm 1.73 b$ & $3.11 \pm 0.78 \mathrm{c}$ & $5.20 \pm 1.86 b$ & $4.34 \pm 0.55 b$ & $4.21 \pm 1.30 \mathrm{a}$ \\
\hline \multicolumn{2}{|c|}{ A. comosus var. comosus } & $10(40)$ & $6.02 \pm 2.48 \mathrm{a}$ & $4.53 \pm 1.73 b$ & $9.27 \pm 3.91 \mathrm{a}$ & $6.28 \pm 1.54 \mathrm{a}$ & $4.48 \pm 1.88 \mathrm{a}$ \\
\hline \multicolumn{2}{|l|}{ Ananas sp. } & $7(28)$ & $4.41 \pm 1.33 b$ & $3.10 \pm 0.41 \mathrm{c}$ & $5.42 \pm 1.42 b$ & $4.55 \pm 0.76 b$ & $3.67 \pm 0.77 \mathrm{a}$ \\
\hline \multicolumn{2}{|l|}{ Hybrids } & $4(16)$ & $6.30 \pm 0.70 \mathrm{a}$ & $4.36 \pm 0.18 b$ & $9.21 \pm 3.13 \mathrm{a}$ & $6.32 \pm 0.95 \mathrm{a}$ & $4.12 \pm 1.50 \mathrm{a}$ \\
\hline \multicolumn{2}{|l|}{ A. macrodontes } & $4(16)$ & $7.14 \pm 0.93 \mathrm{a}$ & $6.13 \pm 0.79 \mathrm{a}$ & $9.73 \pm 1.50 \mathrm{a}$ & $7.29 \pm 0.80 \mathrm{a}$ & $0.00 \mathrm{c}$ \\
\hline \multicolumn{2}{|l|}{ Mean } & & 5.29 & 3.72 & 7.09 & 5.04 & 3.25 \\
\hline \multicolumn{2}{|l|}{$\mathrm{CV}(\%)$} & & 30.27 & 21.18 & 35.44 & 19.68 & 38.81 \\
\hline \multicolumn{2}{|l|}{$\mathrm{Fc}$} & & $12.16 * *$ & $32.19 *$ & $8.00 * *$ & $22.33 * *$ & $12.65^{* *}$ \\
\hline \multicolumn{3}{|l|}{ AS } & 31.27 & 19.97 & 50.57 & 22.01 & 22.77 \\
\hline
\end{tabular}

Means and standard error

Means followed by the same letter are not significantly different by the Scott-Knott test at $1 \%$ probability

$C V(\%)$ coefficient of variation, $F c$ value of the calculated $F$ test, $A S$ average square

$N$ accessions number (plant), $H E I$ plant height, $C A N$ canopy diameter, $L L E$ leaf length ' $\mathrm{D}$ ', $L W I$ leaf width 'D', $L P E$ peduncle length, $D P E$ peduncle diameter, $L I N$ inflorescence length, $D I N$ inflorescence diameter, $S Y L$ syncarp length after closure of the last flower, $S Y D$ syncarp diameter after closure of the last flower, $L C R$ crown length

$* *(P<0.01)$

(Fig. 2e), the syncarp is small, ovoid, with approximately $4.80 \mathrm{~cm}$ in length and $3.60 \mathrm{~cm}$ in diameter, slightly larger than the inflorescence, with scarce and fibrous pulp which make this variety unsuitable to be used as food (Table 5; Fig. 2f).

The A. comosus var. erectifolius differs from $A$. comosus var. ananassoides because it does not present long spines in the edges of the leaves (Souza et al. 2007). The absence of spines and the erect form of the leaves probably result from artificial selection aimed at enhancing larger fiber production and easy leaf manipulation (Coppens D'Eeckenbrugge and Duval 2009).

The genotypes of this variety have characteristics for different uses. The variety is appropriate for landscape plants, since it forms massive. The plants can also be used as cut flower, due to their long and erect peduncle with small syncarp, and minifruits. 
Table 3 Relative contribution $(\%)$ of each plant descriptor in the genetic variation data based on the Singh criterion (1981) and Mahalanobis distance

a $S . j=$ contribution of the variable $x$ for the value of the Euclidean distance between the genotypes $i$ and $i$

\begin{tabular}{lcc}
\hline Descriptors & \multicolumn{1}{c}{$S . j^{\mathrm{a}}$} & $S . j^{\mathrm{a}}(\%)$ \\
\hline Canopy diameter & $2,212,402.60$ & 53.31 \\
Plant height & $812,171.74$ & 19.57 \\
Leaf length 'D' & $634,131.92$ & 15.28 \\
Peduncle length & $432,852.70$ & 10.43 \\
Syncarp length after closure of the last flower & $24,071.33$ & 0.58 \\
Inflorescence length & $11,205.44$ & 0.27 \\
Crown length & $9,132.57$ & 0.22 \\
Syncarp diameter after closure of the last flower & $5,809.34$ & 0.14 \\
Inflorescence diameter & 4.565 .13 & 0.11 \\
Leaf width 'D' & $2,074.93$ & 0.05 \\
Peduncle diameter & 832.32 & 0.02 \\
\hline
\end{tabular}

This variety stands out for its direct use, which has already been taking place, without breeding programs. Nowadays, this variety is largely exported to Europe as cut flower and is responsible for $75 \%$ of the exports of ornamental pineapple (Brainer and Oliveira 2007).

Besides its ornamental use, this variety is widely used for the extraction of fibers of excellent quality, when compared to hemp, sisal, linen, jute, ramie and abaca (Leão et al. 2009). Nowadays, it is cultivated near Belém do Pará (Brazil), for fiber extraction and the manufacture of hammocks, fishing nets (Leal and Amaya 1991) and upholstery of trucks and cars.

The group G3 is formed by two accessions of A. comosus var. parguasensis, Ananas sp. and 25 accessions of A. comosus var. ananassoides.

In Brazil, A. comosus var. parguasensis is called ananaí, kurupira-naná and gravatá. These pineapples grow in places preferably humid and shady, in clearings, gardens or dense forests. They cannot resist in dry places with intense solar radiation.

The leaves presented an average length of $70.32 \mathrm{~cm}$, with usually wavy edges (Table 2). The accessions GF-491 (AGB 775) and FRF-813 (AGB 391) present anthocyanin distribution in their leaves (Fig. 2h, i), which gives them an interesting aspect for landscape plants use. In their natural habitat, their leaves reach up to $2.00 \mathrm{~m}$ long, and their limbo is very broad (Coppens D'Eeckenbrugge and Duval 2009). Their most remarkable difference from A. comosus var. ananassoides is the orientation of some spines in the base of the wide leaves, slightly constricted at the base. Often, it is difficult to distinguish the two varieties due to their similar characteristics.
The syncarps are small, measuring on average $5.20 \mathrm{~cm}$ in length, predominantly globoid. The peduncle is generally winding, long and thin. The accession FRF-691 (AGB 327) presented peduncle with average length of $41.00 \mathrm{~cm}$ and $0.95 \mathrm{~cm}$ in diameter. It is targeted at breeding for cut flower, and can also be used as pot plant due to its low height, below $40.00 \mathrm{~cm}$ (Fig. 2g), which is a small size, considering ordinary pineapples (Tables 4, 5).

Nearly $31 \%$ of the accessions studied are A. comosus var. ananassoides, a variety with wide genetic variation. This variety has genotypes with ornamental characteristics, although some of them are considered undesirable, such as the presence of spines. Duval et al. (1997) report that most populations are monoclonal, but some of them are polyclonal and present morphological variations of sexual origin. The plants generally present an average size, with long and narrow leaves, of up to $1.00 \mathrm{~m}$ in length and ascending spines. The habit ranges from open to decumbent, and most accessions are decumbent.

The accessions Ananaí (AGB 25) and CI-33 (AGB 703) have potential for potted plant due to their reduced size and decumbent habit. However, their use in landscape plants in the form of massive is very interesting. These accessions are called abacaxide-salão and used to be classified as A. nanus (Fig. 2j, $\mathrm{k}$ ) in the former taxonomy. They are marketed in Europe and United States in spite of the presence of spines. The use of this accession as a parent is interesting because of the small size of the fruit, approximately $2.00 \mathrm{~cm}$, a characteristic highly desirable for ornamental pineapple. Some pineapples are 
Fig. 1 Dendrogram of the genetic dissimilarities among 89 accessions of pineapple trees, achieved by the UPGMA method based on the Gower algorithm, from twenty-five qualitative and quantitative characters

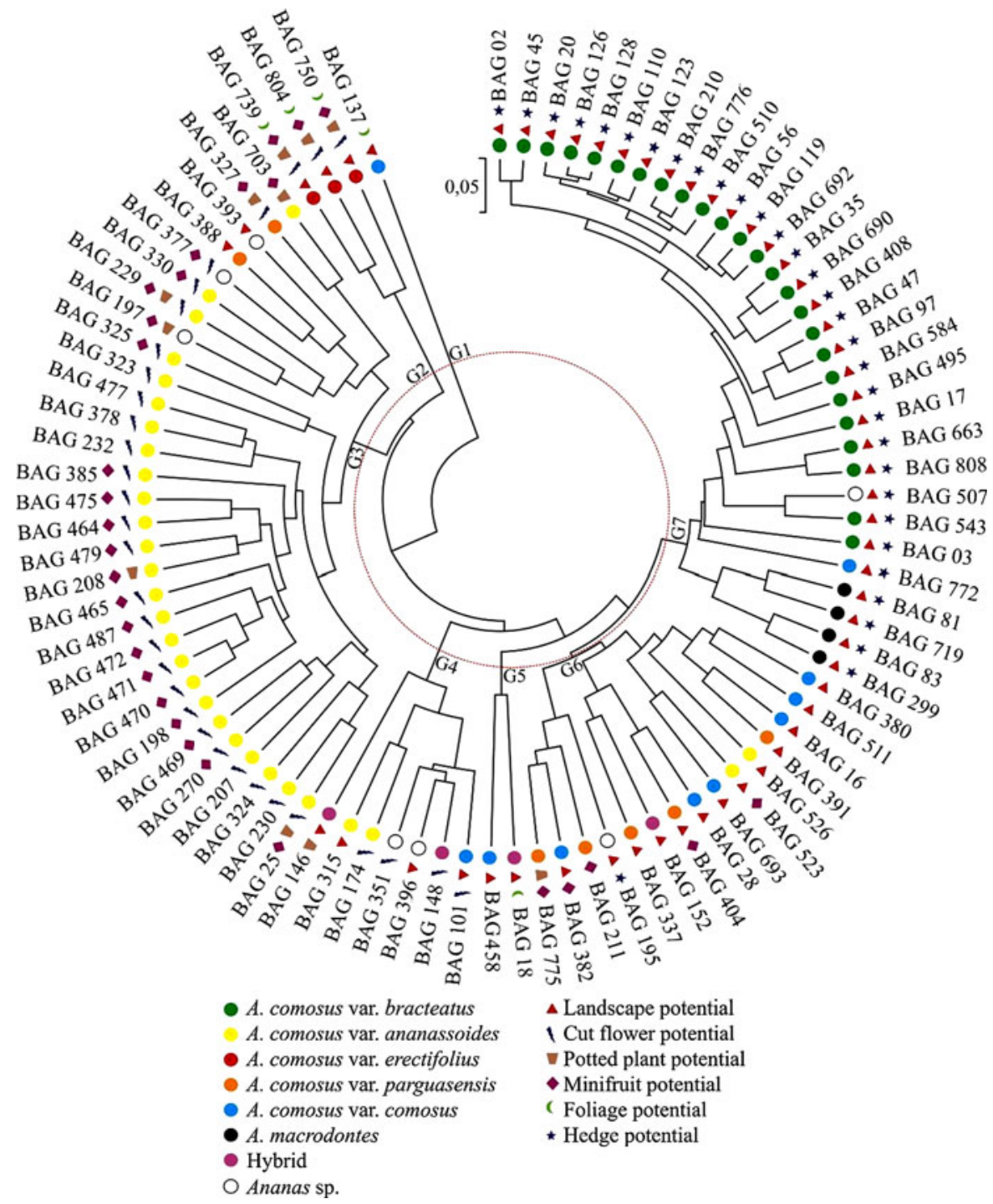

ornamental, but produce large fruits, such as the A. comosus var. bracteatus, which complicates the post-harvest management and increases the cost of transport. The crossing of these genotypes with varieties of very small fruits could determine interesting ornamental variants.

The inflorescences of $A$. comosus var. ananassoides are generally small, with about $2.00-3.00 \mathrm{~cm}$, reaching up to $7.13 \mathrm{~cm}$ in length, which is the case of the accession FRF-52 Ananás do Índio (BGA 174) (Table 5). This is an important characteristic when the the intended use is cut flower, possibly at bud stage or complete fruit (syncarp and crown). The employment of ornamental pineapple for cut at bud stage may be innovative in the flower market and may allow using of many genotypes which are not interesting as complete fruits, but have very attractive buds with a singular beauty, providing differentiated floral arrangements. The shape of the syncarp can be ovoid, globular and cylindrical. They have different colors, but most of them are pinkish. However, the accessions G-35 (AGB 523) and G-44 (AGB 526) were dark purple (Fig. 2m) (Table 5).

The length of the peduncle (stem) is an important characteristic to select genotypes for cut plant, since the market demands stems longer than $40.00 \mathrm{~cm}$. $70.5 \%$ of the accessions evaluated presented peduncles longer than that, which points out the great 
Table 4 Quantitative and qualitative characteristics of the plant in 89 accessions of the pineapple AGB of the Embrapa Cassava \& Fruits with ornamental potential

\begin{tabular}{|c|c|c|c|c|c|c|c|c|c|c|c|}
\hline \multirow[t]{2}{*}{ Genotype } & \multicolumn{11}{|c|}{ Characteristics of the plants } \\
\hline & HAB & HEI & CAN & LLE & LWI & LVA & $\mathrm{COL}$ & ANT & STO & SPI & $\mathrm{CTH}$ \\
\hline AGB 02 & OPE & $97.00 \mathrm{a}$ & $153.75 \mathrm{c}$ & $104.75 a$ & $5.25 b$ & VRM & DGR & PIK & ABS & PRE & DLF \\
\hline AGB 03 & OPE & $90.50 \mathrm{a}$ & $144.00 \mathrm{c}$ & $85.00 \mathrm{~b}$ & $4.40 \mathrm{~b}$ & VRM & DGR & GRE & ABS & PRE & DLF \\
\hline AGB 16 & OPE & $61.33 \mathrm{c}$ & $120.00 \mathrm{e}$ & $61.33 \mathrm{c}$ & $4.07 \mathrm{~b}$ & VPM & ANT & PUR & ABS & PRE & ILF \\
\hline AGB 17 & $\mathrm{DEC}$ & $89.50 \mathrm{a}$ & $187.00 \mathrm{~b}$ & $102.50 \mathrm{a}$ & $4.90 \mathrm{~b}$ & VWM & ANT & PIK & ABS & PRE & DLF \\
\hline AGB 18 & DEC & $63.00 \mathrm{c}$ & $128.33 d$ & $75.67 \mathrm{c}$ & $4.20 \mathrm{~b}$ & VRM & ANT & PUR & ABS & ABS & ABS \\
\hline AGB 20 & OPE & $85.00 \mathrm{~b}$ & $152.25 \mathrm{c}$ & $99.25 \mathrm{a}$ & $4.40 \mathrm{~b}$ & VRM & ANT & PIK & ABS & PRE & DLF \\
\hline AGB 25 & DEC & $41.75 d$ & $73.25 \mathrm{f}$ & $48.25 \mathrm{~d}$ & $2.23 \mathrm{c}$ & WVE & ANT & GRE & ABS & PRE & ILF \\
\hline AGB 28 & OPE & $92.00 \mathrm{a}$ & $134.00 \mathrm{~d}$ & $84.50 \mathrm{~b}$ & $5.40 \mathrm{~b}$ & WVE & LGR & ABS & ABS & PRE & ILF \\
\hline AGB 35 & OPE & $101.50 \mathrm{a}$ & $141.25 \mathrm{c}$ & $88.00 \mathrm{~b}$ & $4.48 b$ & VRM & LGR & PIK & ABS & PRE & DLF \\
\hline AGB 45 & OPE & $85.00 \mathrm{~b}$ & $153.33 \mathrm{c}$ & 95.00 & $4.40 \mathrm{~b}$ & WVE & ANT & PIK & ABS & PRE & DLF \\
\hline AGB 47 & OPE & $102.60 \mathrm{a}$ & $137.60 \mathrm{~d}$ & $70.33 \mathrm{c}$ & $4.00 \mathrm{~b}$ & VRM & DGR & PIK & ABS & PRE & DLF \\
\hline AGB 56 & OPE & $112.00 \mathrm{a}$ & $162.00 \mathrm{c}$ & $109.50 \mathrm{a}$ & $5.13 b$ & VRM & ANT & PIK & ABS & PRE & DLF \\
\hline AGB 81 & OPE & $74.00 \mathrm{~b}$ & $133.25 d$ & $74.00 \mathrm{c}$ & $4.03 \mathrm{~b}$ & WVE & DGR & $\mathrm{ABS}$ & PRE & PRE & DLF \\
\hline AGB 83 & OPE & $73.00 \mathrm{~b}$ & $143.30 \mathrm{c}$ & $85.33 b$ & $3.50 \mathrm{c}$ & WVE & ANT & PIK & PRE & PRE & DLF \\
\hline AGB 97 & OPE & $105.25 a$ & $155.25 \mathrm{c}$ & $95.25 \mathrm{a}$ & $4.28 \mathrm{~b}$ & VRM & ANT & PIK & ABS & PRE & DLF \\
\hline AGB 101 & OPE & $80.67 b$ & $96.67 \mathrm{e}$ & $75.33 \mathrm{c}$ & $3.07 \mathrm{c}$ & WVE & LGR & $\mathrm{ABS}$ & ABS & PRE & ILF \\
\hline AGB 110 & OPE & $99.75 a$ & $166.25 \mathrm{c}$ & $104.00 \mathrm{a}$ & $4.33 b$ & VRM & ANT & PIK & ABS & PRE & DLF \\
\hline AGB 119 & OPE & $106.00 \mathrm{a}$ & $182.75 b$ & $104.00 \mathrm{a}$ & $4.48 b$ & VRM & ANT & PIK & ABS & PRE & DLF \\
\hline AGB 123 & OPE & $109.50 \mathrm{a}$ & $160.75 \mathrm{c}$ & $99.25 \mathrm{a}$ & $4.40 \mathrm{~b}$ & VRM & ANT & PIK & ABS & PRE & DLF \\
\hline AGB 126 & OPE & $85.33 b$ & $157.33 \mathrm{c}$ & $93.00 \mathrm{a}$ & $4.07 \mathrm{~b}$ & VRM & ANT & PIK & ABS & PRE & DLF \\
\hline AGB 128 & OPE & $85.33 b$ & $143.67 \mathrm{c}$ & $89.00 \mathrm{~b}$ & $4.13 b$ & VRM & ANT & PIK & ABS & PRE & DLF \\
\hline AGB 137 & DEC & $89.50 \mathrm{a}$ & $237.00 \mathrm{a}$ & $126.50 \mathrm{a}$ & $8.15 a$ & WVE & ANT & PUR & ABS & PRE & ILF \\
\hline AGB 146 & OPE & $47.33 \mathrm{~d}$ & $80.10 \mathrm{f}$ & $66.00 \mathrm{c}$ & $3.33 \mathrm{c}$ & WVE & LGR & ABS & ABS & PRE & ILF \\
\hline AGB 148 & OPE & $85.25 b$ & $130.25 d$ & $88.50 \mathrm{~b}$ & $4.15 b$ & WVE & LGR & ABS & ABS & PRE & ILF \\
\hline AGB 152 & OPE & $86.50 \mathrm{~b}$ & $121.50 \mathrm{e}$ & $96.00 \mathrm{a}$ & $4.65 b$ & WVE & LGR & ABS & ABS & PRE & DLF \\
\hline AGB 174 & OPE & $81.75 b$ & $154.50 \mathrm{c}$ & $102.75 a$ & $5.38 \mathrm{~b}$ & WVE & DGR & $\mathrm{ABS}$ & ABS & PRE & ILF \\
\hline AGB 195 & DEC & $46.00 \mathrm{~d}$ & $110.67 \mathrm{e}$ & $68.33 c$ & $2.60 \mathrm{c}$ & WVE & ANT & PIK & ABS & PRE & ILF \\
\hline AGB 197 & UND & $45.50 \mathrm{~d}$ & $59.75 \mathrm{f}$ & $35.00 \mathrm{~d}$ & $3.08 \mathrm{c}$ & WVE & LGR & $\mathrm{ABS}$ & ABS & PRE & ILF \\
\hline AGB 198 & OPE & $74.00 \mathrm{~b}$ & $94.50 \mathrm{e}$ & $74.00 \mathrm{c}$ & $2.55 \mathrm{c}$ & WVE & ANT & PIK & ABS & PRE & DLF \\
\hline AGB 207 & DEC & $68.75 b$ & $117.75 \mathrm{e}$ & $65.50 \mathrm{c}$ & $3.55 \mathrm{c}$ & WVE & ANT & PUR & ABS & PRE & ILF \\
\hline AGB 208 & DEC & $58.25 \mathrm{c}$ & $80.00 \mathrm{f}$ & $53.75 \mathrm{~d}$ & $2.43 \mathrm{c}$ & VPM & ANT & PIK & ABS & PRE & DLF \\
\hline AGB 210 & OPE & $88.75 a$ & $151.25 \mathrm{c}$ & $97.75 a$ & $4.13 b$ & VRM & ANT & GRE & ABS & PRE & DLF \\
\hline AGB 211 & OPE & $60.00 \mathrm{c}$ & $102.67 \mathrm{e}$ & $65.00 \mathrm{c}$ & $2.87 \mathrm{c}$ & VGM & ANT & PIK & ABS & PRE & DLF \\
\hline AGB 229 & OPE & $38.50 \mathrm{~d}$ & $77.00 \mathrm{f}$ & $56.50 \mathrm{~d}$ & $2.30 \mathrm{c}$ & WVE & LGR & $\mathrm{ABS}$ & ABS & PRE & ILF \\
\hline AGB 230 & OPE & $76.50 \mathrm{~b}$ & $135.00 \mathrm{~d}$ & $80.00 \mathrm{~b}$ & $2.15 \mathrm{c}$ & WVE & ANT & PIK & ABS & PRE & ILF \\
\hline AGB 232 & DEC & $66.00 \mathrm{~b}$ & $127.00 \mathrm{~d}$ & $88.50 \mathrm{~b}$ & $2.75 \mathrm{c}$ & VRM & LGR & PIK & ABS & PRE & DLF \\
\hline AGB 270 & DEC & $68.50 \mathrm{~b}$ & $97.75 \mathrm{e}$ & $62.50 \mathrm{c}$ & $2.13 \mathrm{c}$ & VPM & ANT & PUR & ABS & PRE & DLF \\
\hline AGB 299 & OPE & $74.00 \mathrm{~b}$ & $148.00 \mathrm{c}$ & $97.50 \mathrm{a}$ & $3.75 \mathrm{c}$ & WVE & DGR & $\mathrm{ABS}$ & PRE & PRE & DLF \\
\hline AGB 315 & OPE & $85.67 b$ & $158.00 \mathrm{c}$ & $99.33 \mathrm{a}$ & $4.77 b$ & WVE & LGR & $\mathrm{ABS}$ & ABS & PRE & ILF \\
\hline AGB 323 & DEC & $107.50 \mathrm{a}$ & $100.50 \mathrm{e}$ & $68.00 \mathrm{c}$ & $2.65 \mathrm{c}$ & WVE & ANT & PUR & ABS & PRE & DLF \\
\hline AGB 324 & OPE & $58.00 \mathrm{c}$ & $79.00 \mathrm{f}$ & $62.50 \mathrm{c}$ & $2.25 \mathrm{c}$ & WVE & ANT & GRE & ABS & PRE & ILF \\
\hline AGB 325 & DEC & $86.50 \mathrm{~b}$ & $145.50 \mathrm{c}$ & $89.50 \mathrm{~b}$ & $2.50 \mathrm{c}$ & WVE & ANT & PUR & ABS & PRE & ILF \\
\hline
\end{tabular}


Table 4 continued

\begin{tabular}{|c|c|c|c|c|c|c|c|c|c|c|c|}
\hline \multirow[t]{2}{*}{ Genotype } & \multicolumn{11}{|c|}{ Characteristics of the plants } \\
\hline & HAB & HEI & CAN & LLE & LWI & LVA & $\mathrm{COL}$ & ANT & STO & SPI & $\mathrm{CTH}$ \\
\hline AGB 327 & $\mathrm{DEC}$ & $39.50 \mathrm{~d}$ & $68.50 f$ & $58.50 \mathrm{~d}$ & $3.35 \mathrm{c}$ & WVE & LGR & $\mathrm{ABS}$ & ABS & PRE & ILF \\
\hline AGB 330 & OPE & $42.00 \mathrm{~d}$ & $69.33 \mathrm{f}$ & $46.67 d$ & $2.37 \mathrm{c}$ & VPM & LGR & ABS & ABS & PRE & DLF \\
\hline AGB 337 & OPE & $79.50 \mathrm{~b}$ & $132.50 \mathrm{~d}$ & $85.50 \mathrm{~b}$ & $4.85 b$ & WVE & ANT & PUR & ABS & PRE & ILF \\
\hline AGB 351 & OPE & $91.00 \mathrm{a}$ & $116.00 \mathrm{e}$ & $89.50 \mathrm{~b}$ & $3.95 b$ & WVE & LGR & $\mathrm{ABS}$ & ABS & PRE & ILF \\
\hline AGB 377 & OPE & $61.25 \mathrm{c}$ & $82.00 \mathrm{f}$ & $65.25 \mathrm{c}$ & $3.63 \mathrm{c}$ & WVE & LGR & ABS & ABS & PRE & ILF \\
\hline AGB 378 & DEC & $7800 \mathrm{~b}$ & $126.50 \mathrm{~d}$ & $85.00 \mathrm{~b}$ & $2.25 \mathrm{c}$ & WVE & LGR & ABS & ABS & PRE & DLF \\
\hline AGB 380 & OPE & $103.50 \mathrm{a}$ & $167.50 \mathrm{c}$ & $100.50 \mathrm{a}$ & $5.00 \mathrm{~b}$ & VRM & LGR & PUR & ABS & PRE & ILF \\
\hline AGB 382 & OPE & $90.67 \mathrm{a}$ & $108.00 \mathrm{e}$ & $95.00 \mathrm{a}$ & $3.57 \mathrm{c}$ & VGM & ANT & GRE & ABS & PRE & DLF \\
\hline AGB 385 & DEC & $41.25 \mathrm{~d}$ & $73.25 \mathrm{f}$ & $47.75 d$ & $1.98 \mathrm{c}$ & VRM & ANT & GRE & ABS & PRE & DLF \\
\hline AGB 388 & OPE & $71.50 \mathrm{~b}$ & $107.25 \mathrm{e}$ & $66.25 \mathrm{c}$ & $3.80 \mathrm{~b}$ & WVE & LGR & $\mathrm{ABS}$ & ABS & PRE & DLF \\
\hline AGB 391 & OPE & $71.50 \mathrm{~b}$ & $121.00 \mathrm{e}$ & $81.50 \mathrm{~b}$ & $4.88 \mathrm{~b}$ & VPM & ANT & PUR & ABS & PRE & DLF \\
\hline AGB 393 & OPE & $80.00 \mathrm{~b}$ & $95.00 \mathrm{e}$ & $104.00 \mathrm{a}$ & $4.53 \mathrm{~b}$ & WVE & LGR & PIK & ABS & PRE & ILF \\
\hline AGB 396 & OPE & $60.33 c$ & $114.67 \mathrm{e}$ & $71.67 \mathrm{c}$ & $3.70 \mathrm{c}$ & WVE & LGR & $\mathrm{ABS}$ & ABS & PRE & DLF \\
\hline AGB 404 & OPE & $71.50 \mathrm{~b}$ & $96.50 \mathrm{e}$ & $69.50 \mathrm{c}$ & $4.15 b$ & WVE & LGR & $\mathrm{ABS}$ & ABS & PRE & DLF \\
\hline AGB 408 & OPE & $104.75 a$ & $152.00 \mathrm{c}$ & $103.00 \mathrm{a}$ & $5.00 \mathrm{~b}$ & VPM & LGR & GRE & ABS & PRE & DLF \\
\hline AGB 458 & DEC & $80.50 \mathrm{~b}$ & $98.50 \mathrm{e}$ & $93.00 \mathrm{a}$ & $7.10 \mathrm{a}$ & VRM & ANT & PUR & ABS & PRE & DLF \\
\hline AGB 464 & DEC & $57.00 \mathrm{c}$ & $98.00 \mathrm{e}$ & $65.50 \mathrm{c}$ & $3.05 \mathrm{c}$ & VPM & ANT & PIK & ABS & PRE & ILF \\
\hline AGB 465 & DEC & $71.33 b$ & $106.67 \mathrm{e}$ & $79.67 \mathrm{~b}$ & $2.70 \mathrm{c}$ & VPM & ANT & PUR & ABS & PRE & DLF \\
\hline AGB 469 & DEC & $48.50 \mathrm{~d}$ & $112.50 \mathrm{e}$ & $79.00 \mathrm{~b}$ & $2.35 \mathrm{c}$ & VPM & ANT & PUR & ABS & PRE & DLF \\
\hline AGB 470 & DEC & $68.75 b$ & $130.50 \mathrm{~d}$ & $82.25 b$ & $3.15 \mathrm{c}$ & VPM & ANT & PIK & ABS & PRE & DLF \\
\hline AGB 471 & DEC & $77.50 \mathrm{~b}$ & $119.50 \mathrm{e}$ & $84.50 \mathrm{~b}$ & $2.68 \mathrm{c}$ & VPM & LGR & PIK & ABS & PRE & DLF \\
\hline AGB 472 & DEC & $74.25 b$ & $102.50 \mathrm{e}$ & $87.00 \mathrm{~b}$ & $3.10 \mathrm{c}$ & VPM & ANT & PIK & ABS & PRE & ILF \\
\hline AGB 475 & DEC & $56.67 \mathrm{c}$ & $108.67 \mathrm{e}$ & $76.67 \mathrm{c}$ & $3.40 \mathrm{c}$ & VPM & LGR & PIK & ABS & PRE & DLF \\
\hline AGB 477 & DEC & $79.50 \mathrm{~b}$ & $136.00 \mathrm{~d}$ & $88.00 \mathrm{~b}$ & $2.75 \mathrm{c}$ & VPM & LGR & PIK & ABS & PRE & DLF \\
\hline AGB 479 & DEC & $54.67 \mathrm{c}$ & $94.67 \mathrm{e}$ & $58.33 d$ & $3.27 \mathrm{c}$ & WVE & ANT & PIK & ABS & PRE & DLF \\
\hline AGB 487 & DEC & $67.50 \mathrm{~b}$ & $120.00 \mathrm{e}$ & $102.50 \mathrm{a}$ & $2.95 \mathrm{c}$ & WVE & ANT & PIK & ABS & PRE & ILF \\
\hline AGB 495 & OPE & $107.25 \mathrm{a}$ & $155.00 \mathrm{c}$ & $96.00 \mathrm{a}$ & $4.60 \mathrm{~b}$ & VRM & ANT & GRE & ABS & PRE & DLF \\
\hline AGB 507 & OPE & $62.25 \mathrm{c}$ & $114.75 \mathrm{e}$ & $83.25 b$ & $4.73 b$ & VRM & ANT & GRE & ABS & PRE & DLF \\
\hline AGB 510 & OPE & $91.00 \mathrm{a}$ & $146.00 \mathrm{c}$ & $94.00 \mathrm{a}$ & $4.48 \mathrm{~b}$ & VRM & ANT & GRE & ABS & PRE & DLF \\
\hline AGB 511 & OPE & $64.50 \mathrm{c}$ & $126.00 \mathrm{~d}$ & $85.50 \mathrm{~b}$ & $4.50 \mathrm{~b}$ & WVE & ANT & PUR & ABS & PRE & ILF \\
\hline AGB 523 & OPE & $63.00 \mathrm{c}$ & $106.00 \mathrm{e}$ & $68.00 \mathrm{c}$ & $3.10 \mathrm{c}$ & VRM & ANT & PIK & ABS & PRE & DLF \\
\hline AGB 526 & OPE & $51.33 \mathrm{c}$ & $65.67 f$ & $47.67 \mathrm{~d}$ & $3.80 \mathrm{~b}$ & WVE & ANT & PUR & ABS & PRE & ILF \\
\hline AGB 543 & OPE & $97.00 \mathrm{a}$ & $158.00 \mathrm{c}$ & $92.50 \mathrm{a}$ & $4.73 b$ & WVE & ANT & PIK & ABS & PRE & DLF \\
\hline AGB 584 & OPE & $93.00 \mathrm{a}$ & $141.00 \mathrm{c}$ & $95.00 \mathrm{a}$ & $5.00 \mathrm{~b}$ & VRM & ANT & PIK & ABS & PRE & DLF \\
\hline AGB 663 & OPE & $63.67 \mathrm{c}$ & $122.33 \mathrm{e}$ & $77.33 \mathrm{c}$ & $4.10 \mathrm{~b}$ & VRM & ANT & GRE & ABS & PRE & DLF \\
\hline AGB 690 & OPE & $96.50 \mathrm{a}$ & $152.75 \mathrm{c}$ & $102.00 \mathrm{a}$ & $4.80 \mathrm{~b}$ & VRM & LGR & GRE & ABS & PRE & DLF \\
\hline AGB 692 & OPE & $105.50 \mathrm{a}$ & $135.50 \mathrm{~d}$ & $105.00 \mathrm{a}$ & $5.00 \mathrm{~b}$ & VRM & ANT & GRE & ABS & PRE & DLF \\
\hline AGB 693 & OPE & $47.00 \mathrm{~d}$ & $105.00 \mathrm{e}$ & $62.50 \mathrm{c}$ & $3.90 \mathrm{~b}$ & VPM & ANT & PUR & ABS & PRE & DLF \\
\hline AGB 703 & DEC & $39.25 \mathrm{~d}$ & $64.50 \mathrm{f}$ & $39.75 d$ & $2.63 \mathrm{c}$ & WVE & LGR & $\mathrm{ABS}$ & ABS & PRE & ILF \\
\hline AGB 719 & OPE & $77.00 \mathrm{~b}$ & $130.00 \mathrm{~d}$ & $86.50 \mathrm{~b}$ & $4.60 \mathrm{~b}$ & VRM & ANT & GRE & PRE & PRE & DLF \\
\hline AGB 739 & ERE & $84.67 \mathrm{~b}$ & $90.33 \mathrm{f}$ & $83.00 \mathrm{~b}$ & $4.10 \mathrm{~b}$ & WVE & ANT & PUR & ABS & ABS & ABS \\
\hline AGB 750 & ERE & $78.25 b$ & $76.50 \mathrm{f}$ & $53.75 d$ & $3.03 \mathrm{c}$ & VRM & ANT & GRE & ABS & ABS & ABS \\
\hline AGB 772 & OPE & $51.50 \mathrm{c}$ & $66.50 f$ & $67.00 \mathrm{c}$ & $3.75 \mathrm{c}$ & VRM & ANT & GRE & ABS & PRE & DLF \\
\hline
\end{tabular}


Table 4 continued

\begin{tabular}{llrrllllllll}
\hline Genotype & \multicolumn{2}{l}{ Characteristics of the plants } \\
\cline { 2 - 10 } & HAB & \multicolumn{1}{ll}{ HEI } & \multicolumn{1}{c}{ CAN } & LLE & LWI & LVA & COL & ANT & STO & SPI & CTH \\
\hline AGB 775 & OPE & $44.00 \mathrm{~d}$ & $80.00 \mathrm{f}$ & $66.00 \mathrm{c}$ & $4.35 \mathrm{~b}$ & WVE & ANT & GRE & ABS & PRE & DLF \\
AGB 776 & OPE & $92.50 \mathrm{a}$ & $150.00 \mathrm{c}$ & $94.50 \mathrm{a}$ & $4.78 \mathrm{~b}$ & VPM & ANT & GRE & ABS & PRE & DLF \\
AGB 804 & ERE & $69.00 \mathrm{~b}$ & $73.75 \mathrm{f}$ & $56.25 \mathrm{~d}$ & $3.25 \mathrm{c}$ & VGM & ANT & PUR & ABS & ABS & ABS \\
AGB 808 & OPE & $64.00 \mathrm{c}$ & $121.50 \mathrm{e}$ & $76.50 \mathrm{c}$ & $4.00 \mathrm{~b}$ & VRM & ANT & GRE & ABS & PRE & DLF \\
\hline
\end{tabular}

Averages followed by the same letter do not differ by the Scott-Knott test at $1 \%$ probability

$H A B$ plant habit, $H E I$ plant height $(\mathrm{cm}), C A N$ canopy diameter $(\mathrm{cm}), L L E$ leaf length 'D' (cm), LWI leaf width 'D' (cm), LVA leaf variegation, $C O L$ color of the leaves, $A N T$ presence of anthocyanin, $S T O$ stolon, SPI spinescence, $C T H$ color of the spines, $A B S$ absent, $P U R$ purple, $D E C$ decumbent, $D L F$ different from leaf, ERE erect, $I L F$ similar to leaf, $L G R$ light green, $O P E$ open, $P R E$ present, $P I K$ pink, $U N D$ undetermined, GRE green, $V G M$ variegation with green margin, $V P M$ variegation with purple margin, $V R M$ variegation with red margin, $V W M$ variegation with white margin, $W V E$ without variegation

potential of this variety to be used as parent in crossings targeting hybrids for this purpose. The average length observed in the accessions evaluated was $50.55 \mathrm{~cm}$, while the variation was from $10.95 \mathrm{~cm}$ in the accession G-35 (AGB 523) to $80.50 \mathrm{~cm}$ in the accession FRF-372 (AGB 230) (Table 5).

For the diameter of the peduncle, the average observed was $0.78 \mathrm{~cm}$, varying from 0.45 to $1.83 \mathrm{~cm}$ (Tables 2, 5). Thin peduncles with good resistance to syncarp dropping are desirable, since weight affects the cost of transport, mainly for export.

Concerning the shape of the peduncle, it is worth mentioning that the European market demands erect peduncles without any deformation, although sinuous peduncles are interesting for floral arrangements. The results of this work demonstrated that $35.3 \%$ of the characterized accessions have erect peduncles while $64.7 \%$ have sinuous peduncles.

Cut flowers must present well formed and small syncarps, with intense color and crown/syncarp relation lower or equal to one. Syncarps lower than $5.00 \mathrm{~cm}$ in diameter were recorded in 12 accessions.

Groups G4, G5 and G6 comprise accessions of A. comosus var. ananassoides, A. comosus var. parguasensis, A. comosus var. comosus, Ananas sp. and hybrids from crossings previously carried out for genetic breeding for food use. These accessions stood out mainly due to their ornamental characteristics and were thus included in the evaluation proposed in this work.

The hybrid resulting from the crossing between A. comosus var. bracteatus and A. comosus var. comosus, the Ananás S. Bento $\times$ Local de Tefé, presents a strong ornamental potential for landscape plants, with open habit, average height of $47.33 \mathrm{~cm}$, reddish syncarps, greenish crown and great contrast for ornamentation (Table 4). The plant presents few spines distributed along the leaves, the crown is small $(4.37 \mathrm{~cm})$ and the syncarp is cylindrical, forming an extremely attractive fruit, mainly by the contrast with the greenish crown (Table 5; Fig. 3a).

The accession Smooth Cayenne $\times$ Ananaí (AGB 148 ) is a hybrid resulting from the crossing of A. comosus var. comosus and A. comosus var. ananassoides. This accession presents a long and erect peduncle $(42.75 \mathrm{~cm})$, and a light pink cylindrical syncarp with average length of $8.23 \mathrm{~cm}$ (Table 5). Its leaves are long $(88.50 \mathrm{~cm})$ and thin $(4.14 \mathrm{~cm})$, with few spines distributed along them, a characteristic probably inherited from the parent Ananaí (Table 4; Fig. 3b).

The accession Pseudananas $\times$ Rondon (AGB 146) is a hybrid resulting from the crossing of $A$. macrodontes and A. comosus var. comosus, whose leaves are long $(101.00 \mathrm{~cm})$, wide $(5.80 \mathrm{~cm})$, glossy and free from spines, with great concentration of anthocyanin (Table 4). Its inflorescence is purplish-red, large and extremely attractive (Fig. 3c). Its syncarp is long $(13.83 \mathrm{~cm})$, dark red and trapezoidal, with wide base at fruit stage. The crown is very small $(1.93 \mathrm{~cm})$ and almost absent (Table 5; Fig. 3d).

The accessions of Ananas sp. are distributed into different groups, which demonstrates that it is difficult to classify the genus taxonomically. These accessions do not show a clear classification pattern, and further research works on molecular markers are needed. Most of them are similar to the A. comosus var. 

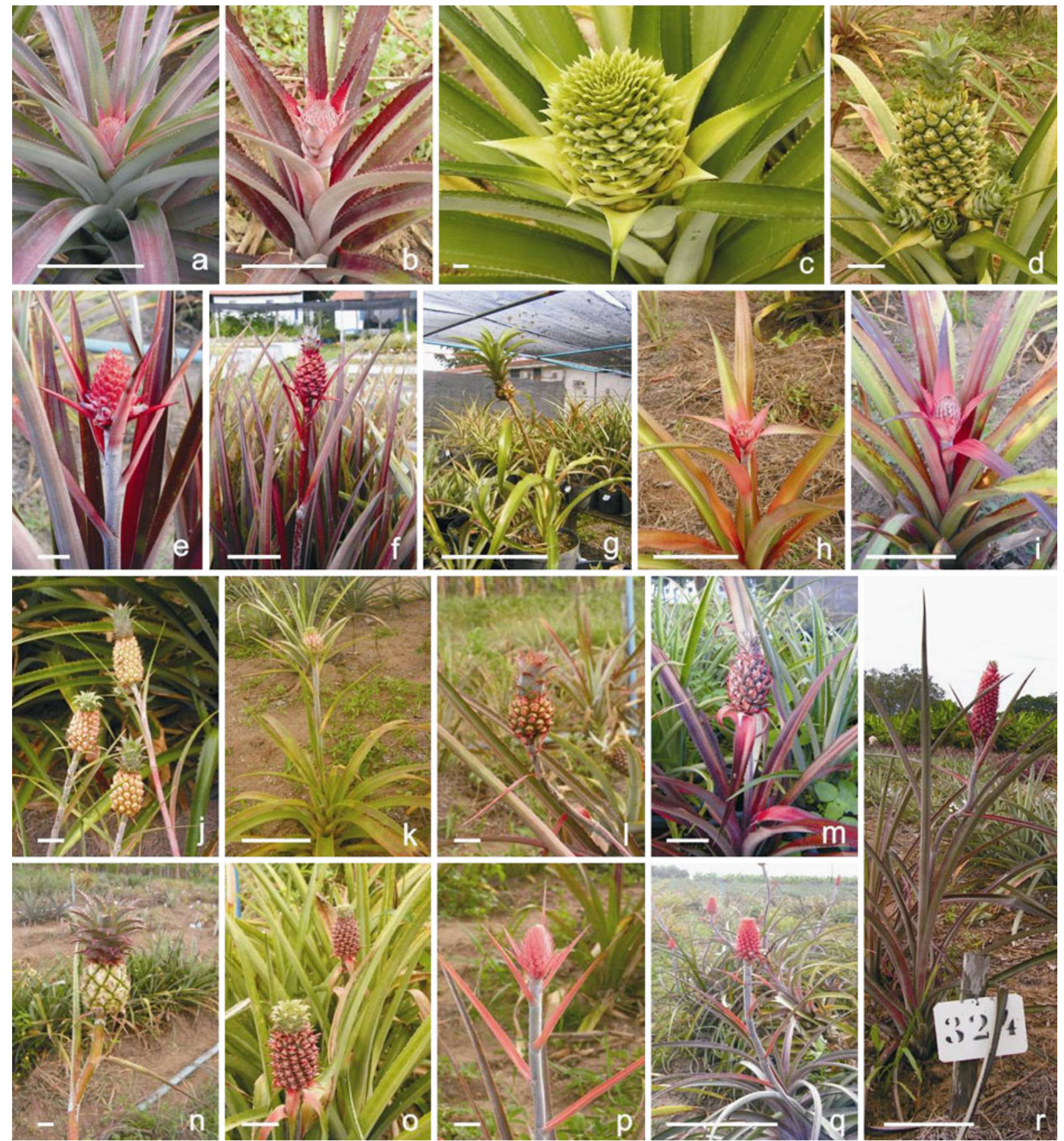

Fig. 2 Genetic variation among pineapple trees with ornamental potential. a-d A. comosus var. comosus; a Arroba Tarauacá (AGB 137); b Roxo de Tefé (AGB 16); c detail of the inflorescence, accession Branco (AGB 28); d Branco (AGB 28). e-f $A$. comosus var. erectifolius; e detail of the bud, accession FFR-1387 (AGB 804); f Curauá Roxo (AGB 739). g-i A. comosus var. parguasensis; g FRF-691 (AGB 327); h GF-491
(AGB 775); i FRF-813 (AGB 391). j-r A. comosus var. ananassoides; j Ananaí (AGB 25); k CI-33 (AGB 703); l LBB1446 (AGB 465); m G-44 (AGB 526); n FRF-372 (AGB 330); o DCG-876 (AGB 315); p detail of the bud of the accession Valls 9385 (AGB 324); q detail of the bud, accession GHAV E JMTM-11 (AGB 323) and $\mathbf{r}$ detail of the sinuous peduncle, accession Valls 9385 (AGB 324). Bar $=1.00 \mathrm{~cm}$ 
Table 5 Quantitative and qualitative characteristics of peduncle, inflorescence, syncarp and crown in 89 accessions of the pineapple AGB of the Embrapa Cassava \& Fruits with ornamental potential

\begin{tabular}{|c|c|c|c|c|c|c|c|c|c|c|c|c|c|c|}
\hline \multirow[t]{2}{*}{ Genotype } & \multicolumn{14}{|c|}{ Characteristics of the peduncle, inflorescence, syncarp and crown } \\
\hline & PE & DPE & SPE & $\mathrm{CPE}$ & LIN & DIN & SYL & SYD & LCR & SSY & $\mathrm{PBC}$ & $\mathrm{CBC}$ & CSF & CSD \\
\hline AGB 02 & . & t & RE & 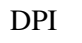 & 1000 & ( & 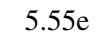 & $5.75 b$ & $5 \mathrm{c}$ & 20. & ABS & Th & 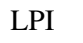 & DPI \\
\hline AGB 03 & $3.00 \mathrm{f}$ & 1 & $\mathrm{E}$ & I & $7.00 \mathrm{c}$ & $\mathrm{d}$ & $10.25 \mathrm{c}$ & $5.90 \mathrm{~b}$ & $3.35 \mathrm{e}$ & OVO & ABS & $\mathrm{ABS}$ & DRE & BUR \\
\hline AGB 16 & $19.00 \mathrm{~h}$ & $2.07 \mathrm{~b}$ & ERE & $\mathrm{RE}$ & $6.77 \mathrm{c}$ & $4.47 \mathrm{~d}$ & $7.50 \mathrm{e}$ & $5.83 b$ & $4.73 c$ & CYL & ABS & $\mathrm{ABS}$ & LPU & DPI \\
\hline AGB 17 & $3.25 \mathrm{f}$ & $1.45 \mathrm{~d}$ & ERE & 1 & $48 \mathrm{c}$ & $d$ & $30 \mathrm{e}$ & $5.73 b$ & $5 b$ & TRA & ABS & ABS & $\mathrm{D}$ & DPI \\
\hline AGB 18 & $.00 \mathrm{~g}$ & 1. & ERE & D & $\mathrm{c}$ & 4 & $3 b$ & $7.73 b$ & 1 & A & ABS & $\mathrm{ABS}$ & RE & DGR \\
\hline AGB 20 & $27.25 \mathrm{f}$ & $2.00 \mathrm{~b}$ & E & D & $\mathrm{d}$ & & $7.27 \mathrm{e}$ & $6.40 \mathrm{~b}$ & $0 \mathrm{c}$ & TRA & ABS & $\mathrm{ABS}$ & DPI & DPI \\
\hline GB 25 & $75 d$ & $\mathrm{~h}$ & ERE & 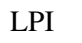 & 2 & h & 3 & $75 \mathrm{c}$ & 2 & ese & ABS & $\mathrm{ABS}$ & $\mathrm{E}$ & CRE \\
\hline AGB 28 & 5.501 & $2.35 \mathrm{a}$ & ERE & LGR & $5 \mathrm{c}$ & 4 & & $5.95 b$ & & TRA & $\mathrm{ABS}$ & $\mathrm{ABS}$ & LGR & LGR \\
\hline AGB 35 & $25.50 \mathrm{~g}$ & $2.00 \mathrm{~b}$ & ERE & DPI & $d$ & $5.00 \mathrm{~d}$ & $3 d$ & $7.40 \mathrm{~b}$ & $\mathrm{~d}$ & TRA & ABS & ABS & DPI & DPI \\
\hline AGB 45 & $.00 \mathrm{~g}$ & $1.87 \mathrm{c}$ & RE & 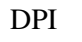 & $00 \mathrm{~d}$ & 5 & e & $73 b$ & $5.60 \mathrm{c}$ & $\mathrm{T}$ & $\mathrm{ABS}$ & $\mathrm{ABS}$ & $\mathrm{L}$ & DPI \\
\hline AGB 47 & $.67 \mathrm{~h}$ & $1.87 \mathrm{c}$ & ERE & PI & $03 \mathrm{~b}$ & 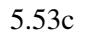 & $3 d$ & $6.37 \mathrm{~b}$ & & TRA & $3 S$ & ABS & L & LPI \\
\hline AGB 56 & $29.00 \mathrm{f}$ & $2.20 \mathrm{~b}$ & ERE & DPI & d & 4 & $11.88 \mathrm{c}$ & $6.45 b$ & $8.23 a$ & TRA & ABS & $\mathrm{ABS}$ & DPI & DPI \\
\hline AGB 81 & & 2 & $E$ & - & & 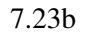 & $5 d$ & $3 a$ & $\mathrm{~g}$ & - & ABS & $\mathrm{ABS}$ & $\mathrm{E}$ & DGR \\
\hline GB 83 & $00 \mathrm{~g}$ & & ERE & & & & & $6.60 \mathrm{~b}$ & & & ABS & ABS & & LPI \\
\hline AGB 97 & $75 \mathrm{~h}$ & $2.20 \mathrm{~b}$ & ERE & DPI & & 5 & $0 \mathrm{~d}$ & $7.38 b$ & & $\mathrm{TR}$ & ABS & $\mathrm{ABS}$ & $\mathrm{L}$ & LPI \\
\hline AGB 101 & 4 & 2 & $E$ & $\mathrm{I}$ & $5.83 \mathrm{~d}$ & $5.03 d$ & d & b & $6.77 b$ & & RE & LPI & LPI & LPI \\
\hline AGB 110 & $75 \mathrm{~g}$ & & ERE & 1 & & & 1.100 & $8 b$ & & & $\mathrm{ABS}$ & $\mathrm{ABS}$ & & DPI \\
\hline AGB 119 & $31.50 \mathrm{f}$ & $2.10 \mathrm{~b}$ & ERE & DPI & $6.68 \mathrm{c}$ & 5 & $.05 \mathrm{c}$ & $6.93 b$ & 5. & TRA & ABS & ABS & DPI & DPI \\
\hline AGB 123 & g & 2 & $\mathrm{E}$ & 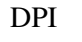 & 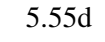 & 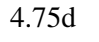 & d & $8 \mathrm{~b}$ & 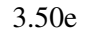 & - & ABS & ABS & 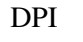 & DPI \\
\hline AGB 126 & $3 \mathrm{~g}$ & & & 1 & & & 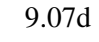 & $7 \mathrm{~b}$ & & & ABS & ABS & & DPI \\
\hline AGB 128 & $28.33 \mathrm{f}$ & $1.87 \mathrm{c}$ & ERE & PI & & & & $3 b$ & & & ABS & ABS & & DPI \\
\hline AGB 137 & $.00 \mathrm{~h}$ & $2.55 \mathrm{a}$ & RE & LPU & $\mathrm{a}$ & 8 & $5 a$ & $5 a$ & 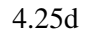 & C & ABS & $\mathrm{BS}$ & U & DPI \\
\hline GB 146 & h & 1 & $E$ & $\mathrm{I}$ & $7.00 \mathrm{c}$ & & & b & & & $\mathrm{E}$ & $\mathrm{R}$ & $E$ & LRE \\
\hline AGB 148 & 100 & $1.90 \mathrm{c}$ & LSI & PI & $\mathrm{d}$ & & & $5.63 b$ & & $\mathrm{C}$ & PRE & LPI & & LPI \\
\hline AGB 152 & $00 \mathrm{~h}$ & 1 & ERE & DPI & 5 & 4 & 6 & $\mathrm{Ob}$ & 5 & $\mathrm{O}$ & ABS & ABS & $\mathrm{E}$ & DPI \\
\hline AGB 174 & & & ERE & Ex & & & & & 5.150 & C1 & ABS & $\mathrm{ABS}$ & 2 & LPI \\
\hline AGB 195 & $50.55 e$ & $0.70 \mathrm{~g}$ & ERE & D11 & & 2.071 & S & $3.90 \mathrm{c}$ & $4.97 \mathrm{c}$ & GLO & ABS & ABS & DPU & DPI \\
\hline AGB 197 & $5 f$ & $\mathrm{~h}$ & LSI & LPI & e & 2. & of & $3.40 \mathrm{c}$ & 3 & $\mathrm{TI}$ & ABS & $\mathrm{ABS}$ & $\mathrm{L}$ & LPI \\
\hline AGB 198 & 4 & 0 & RE & LPI & & & & & & & ABS & ABS & & LPI \\
\hline AGB 207 & $48.50 \mathrm{~d}$ & $0.83 \mathrm{~g}$ & LSI & LPI & e & 2.4 & 0.45 & $3.93 \mathrm{c}$ & $2.65 \mathrm{e}$ & $\mathrm{L}$ & ABS & ABS & DGR & DGR \\
\hline AGB 208 & $33.25 \mathrm{f}$ & $0.65 \mathrm{~h}$ & LSI & $\mathrm{L}$ & 2 & h & 3.6 & $3.08 \mathrm{c}$ & $1.30 \mathrm{f}$ & G & ABS & $\mathrm{ABS}$ & $\mathrm{L}$ & DGR \\
\hline GB 210 & $23.00 \mathrm{~g}$ & $1.68 \mathrm{c}$ & ERE & PI & & & & $6.33 b$ & & $\mathrm{TH}$ & S & S & & DPI \\
\hline AGB 211 & $t$ & & $\mathrm{E}$ & & & & & & & & S & $S$ & PU & PI \\
\hline AGB 229 & $50 \mathrm{e}$ & $0 \mathrm{~g}$ & ERE & LPI & $3.55 \mathrm{e}$ & $2.35 \mathrm{~g}$ & 2. & $3.05 \mathrm{c}$ & $1.55 \mathrm{f}$ & $\mathrm{L}$ & ABS & ABS & LPI & LPI \\
\hline AGB 230 & . & $0.85 \mathrm{~g}$ & ERE & LPI & . & $2.50 \mathrm{~g}$ & $5.80 \mathrm{e}$ & $3.80 \mathrm{c}$ & $2.00 \mathrm{f}$ & CYL & $\mathrm{ABS}$ & $\mathrm{ABS}$ & CRE & CRE \\
\hline AGB 232 & $58.50 \mathrm{c}$ & $0.95 \mathrm{f}$ & LSI & LPI & $3.25 \mathrm{f}$ & $2.40 \mathrm{~g}$ & $6.80 \mathrm{e}$ & $4.50 \mathrm{c}$ & $3.60 \mathrm{e}$ & CYL & ABS & ABS & CRE & CRE \\
\hline AGB 270 & $51.50 \mathrm{~d}$ & $0.63 \mathrm{~h}$ & ERE & LPI & $2.78 \mathrm{f}$ & $1.93 \mathrm{~h}$ & $4.38 \mathrm{f}$ & $2.98 \mathrm{c}$ & $1.33 \mathrm{f}$ & CYL & ABS & ABS & DPI & DPI \\
\hline AGB 299 & $28.00 \mathrm{f}$ & $2.20 \mathrm{~b}$ & ERE & LPI & $7.80 \mathrm{c}$ & $5.35 \mathrm{c}$ & $11.60 \mathrm{c}$ & $7.25 b$ & $0.00 \mathrm{~g}$ & CYL & ABS & $\mathrm{ABS}$ & LPI & LPI \\
\hline AGB 315 & $36.67 \mathrm{e}$ & $1.57 \mathrm{~d}$ & ERE & $\mathrm{L}$ & 0. & 5.170 & 0.050 & $4.47 \mathrm{c}$ & 2.530 & $C_{1}$ & $S$ & $S$ & DPI & DPI \\
\hline AGB 323 & $52.00 \mathrm{~d}$ & $1.05 \mathrm{f}$ & LSI & DPU & $5.60 \mathrm{~d}$ & 4.2 & 7. & $4.65 c$ & $3.08 \mathrm{e}$ & OVO & ABS & $\mathrm{ABS}$ & DPI & DPI \\
\hline $\mathrm{AC}$ & 6 & h & $\mathrm{N}$ & $\mathrm{L}$ & & & & $\mathrm{c}$ & 2.000 & & $S$ & $S$ & PI & DPI \\
\hline AGB 325 & $76.50 \mathrm{a}$ & $1.00 \mathrm{f}$ & MSI & DPI & $3.90 \mathrm{e}$ & $2.90 \mathrm{f}$ & $5.00 \mathrm{e}$ & $3.30 \mathrm{c}$ & $0.35 \mathrm{~g}$ & CYL & $\mathrm{ABS}$ & $3 S$ & DPI & PI \\
\hline
\end{tabular}


Table 5 continued

\begin{tabular}{|c|c|c|c|c|c|c|c|c|c|c|c|c|c|c|}
\hline \multirow[t]{2}{*}{ Genotype } & \multicolumn{14}{|c|}{ Characteristics of the peduncle, inflorescence, syncarp and crown } \\
\hline & $\mathrm{E}$ & $\mathrm{PF}$ & $\mathrm{PF}$ & $\mathrm{PE}$ & LIN & DIN & SYL & SYD & $\mathrm{CR}$ & SY & $\mathrm{PBC}$ & $\mathrm{BC}$ & CSF & $\mathrm{SSD}$ \\
\hline GB 327 & & & Fis & & & & & & $6.90 \mathrm{~b}$ & & & צטה & YEL & ה \\
\hline AGB 330 & $8.00 \mathrm{e}$ & $0.50 \mathrm{~h}$ & LSI & PI & $2.30 \mathrm{f}$ & & & & $1.60 \mathrm{f}$ & VO & ABS & ABS & LPI & $\mathrm{RE}$ \\
\hline GB 337 & $25.50 \mathrm{~g}$ & $1.40 \mathrm{e}$ & $\mathrm{RF}$ & $\mathrm{F}$ & $7.50 \mathrm{c}$ & 4 & $5 d$ & $5.05 \mathrm{~b}$ & $4.60 \mathrm{~d}$ & $\mathrm{VO}$ & $3 S$ & $3 S$ & $\mathrm{U}$ & GR \\
\hline GB 351 & $50.00 \mathrm{~d}$ & $2.45 \mathrm{a}$ & & & & & & & & & & & & PI \\
\hline AGB 377 & $39.75 \mathrm{e}$ & $0.60 \mathrm{~h}$ & LSI & LPI & $f$ & & & & & & ABS & ABS & DRE & DGR \\
\hline AGB 378 & $.00 \mathrm{~b}$ & g & LSI & 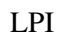 & Of & $2.15 \mathrm{~g}$ & $10 \mathrm{e}$ & & $30 \mathrm{e}$ & & ABS & $\mathrm{ABS}$ & LPI & LGR \\
\hline GB 380 & & $2.00 \mathrm{~b}$ & RE & & & & & & & & & & & PI \\
\hline AGB 382 & $28.33 \mathrm{f}$ & 1. & ERE & & 2.8 & & & & & & BS & & & GR \\
\hline GB 385 & & & 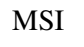 & $\mathrm{I}$ & $\mathrm{f}$ & & & & & & & & $\mathrm{L}$ & YEL \\
\hline GB 388 & & & & & & & & & & & & & & DGR \\
\hline GB 391 & $50 \mathrm{~h}$ & & ERE & & $5.93 \mathrm{~d}$ & & & & & & & & & GR \\
\hline AGB 393 & 3 & 1. & L & $\mathrm{L}$ & $0 \mathrm{e}$ & f & & $7 \mathrm{~b}$ & $d$ & & $3 S$ & $3 S$ & LPU & DPI \\
\hline GB 396 & & & & & & & & & & & & & & LPI \\
\hline GB 404 & $36.00 \mathrm{e}$ & & ERE & LGR & $4.05 \mathrm{e}$ & & & & & & & & $\mathrm{SR}$ & GR \\
\hline AGB 408 & 31. & 1. & ERE & DPI & $\mathrm{a}$ & 5 & $c$ & b & $d$ & & & & & DPI \\
\hline GB 458 & & & & & & & & & & & & & & GR \\
\hline GB 464 & 年 & & & & & & & & & & & & & DGR \\
\hline AGB 465 & 5 & $\mathrm{~g}$ & $\mathrm{~N}$ & DPI & 2. & $\mathrm{~h}$ & 3 & $3 c$ & f & & & & & LPI \\
\hline GB 469 & & & $\mathrm{E}$ & I PI & & & & & & & A & & DGR & GR \\
\hline GB 470 & & & & & & & & & & & & & & PI \\
\hline AGB 471 & $\mathrm{~b}$ & $\mathrm{~g}$ & $\mathrm{~N}$ & & $8 f$ & 1 & & & $8 f$ & & & & & LPI \\
\hline AGB 472 & & & & & & & & & & & & & & LPI \\
\hline GB 475 & & & & & & & & & & & & & & PI \\
\hline GB 477 & & & & & & & & & & & & & & RA \\
\hline AGB 479 & $38.67 \mathrm{e}$ & $\mathrm{h}$ & L & LPI & $2.93 \mathrm{f}$ & $\mathrm{g}$ & $3 c$ & & ff & & & & & CRE \\
\hline GB 487 & & & & & & & & & & & & & & PI \\
\hline В 495 & & & & & & & & & & & & & & DPI \\
\hline AGB 507 & $\mathrm{~h}$ & & $E$ & DPI & d & & & & & & & & & LGR \\
\hline AGB 510 & & & & & & & & & & & & & & PI \\
\hline GB 511 & & & & & & & & & & & & & & BUR \\
\hline AGB 523 & $5 \mathrm{~h}$ & & 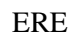 & & & & & & & & & & & DPI \\
\hline AGB 526 & & & $\mathrm{E}$ & & & & & & & & & & & DPI \\
\hline AGB 543 & & & & & & & & & & & & & & DGR \\
\hline AGB 584 & $24.50 \mathrm{~g}$ & & EI & 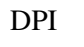 & & 5. & $0 \mathrm{c}$ & $\mathrm{Ob}$ & - & & $S$ & & I & LPI \\
\hline AGB 663 & & & & & & & & & & & & & & DPI \\
\hline AGB 690 & $27.00 \mathrm{~g}$ & $1.95 \mathrm{c}$ & ERE & & & & & & & & & & & DPI \\
\hline AGB 692 & $31.00 \mathrm{f}$ & $2.20 \mathrm{~b}$ & ERE & DPI & $10.00 \mathrm{a}$ & $5.55 \mathrm{c}$ & $11.40 \mathrm{c}$ & $b$ & $4.85 \mathrm{c}$ & TRA & ABS & ABS & DPI & DPI \\
\hline AGB 693 & & & & & & & & & & & & & & DPI \\
\hline AGB 703 & $34.25 f$ & & ERE & & $2.38 \mathrm{f}$ & $0.80 \mathrm{~h}$ & & & $4.13 \mathrm{~d}$ & & & & & LGR \\
\hline AGB 719 & $28.50 \mathrm{f}$ & $2.25 b$ & ERE & DPI & $6.30 \mathrm{c}$ & $5.95 \mathrm{c}$ & $10.10 \mathrm{c}$ & $6.90 \mathrm{~b}$ & $0.00 \mathrm{~g}$ & TRA & ABS & ABS & DRE & DGR \\
\hline AGB 739 & & & & & & & & & & OVO & $\mathrm{ABS}$ & & & LRE \\
\hline AGB 750 & $41.00 \mathrm{e}$ & $0.78 \mathrm{~g}$ & ERE & DKE & $2.33 \mathrm{f}$ & 1.0011 & & & & OVO & ABS & $\mathrm{ABS}$ & DRE & ה \\
\hline AGB 772 & $26.50 \mathrm{~g}$ & $2.05 \mathrm{~b}$ & ERE & DPI & $4.05 \mathrm{e}$ & $3.80 \mathrm{e}$ & $6.85 \mathrm{e}$ & $5.15 b$ & $5.15 \mathrm{c}$ & GLO & ABS & $\mathrm{ABS}$ & LPI & ORA \\
\hline
\end{tabular}


Table 5 continued

\begin{tabular}{lllllllllllllllll}
\hline Genotype & \multicolumn{10}{l}{ Characteristics of the peduncle, inflorescence, syncarp and crown } \\
\cline { 2 - 12 } & LPE & DPE & SPE & CPE & LIN & DIN & SYL & SYD & LCR & SSY & PBC & CBC & CSF & CSD \\
\hline AGB 775 & $16.50 \mathrm{~h}$ & $0.90 \mathrm{~g}$ & ERE & LRE & $3.50 \mathrm{e}$ & $2.50 \mathrm{~g}$ & $3.00 \mathrm{f}$ & $3.50 \mathrm{c}$ & $3.50 \mathrm{e}$ & GLO & ABS & ABS & DGR & DGR \\
AGB 776 & $31.25 \mathrm{f}$ & $1.75 \mathrm{c}$ & ERE & DPI & $7.50 \mathrm{c}$ & $4.88 \mathrm{~d}$ & $8.95 \mathrm{~d}$ & $6.33 \mathrm{~b}$ & $5.10 \mathrm{c}$ & TRA & ABS & ABS & DPI & DPI \\
AGB 804 & $41.50 \mathrm{e}$ & $1.00 \mathrm{f}$ & ERE & DRE & $4.15 \mathrm{e}$ & $2.45 \mathrm{~g}$ & $4.43 \mathrm{f}$ & $3.10 \mathrm{c}$ & $2.65 \mathrm{e}$ & OVO & ABS & ABS & DRE & DGR \\
AGB 808 & $15.50 \mathrm{~h}$ & $1.05 \mathrm{f}$ & ERE & LPI & $5.20 \mathrm{~d}$ & $3.80 \mathrm{e}$ & $5.45 \mathrm{e}$ & $4.30 \mathrm{c}$ & $3.75 \mathrm{~d}$ & TRA & ABS & ABS & DPI & DPI \\
\hline
\end{tabular}

Averages followed by the same letter do not differ by the Scott-Knott test at $1 \%$ probability

$L P E$ peduncle length, DPE peduncle diameter, SPE shape of the peduncle, CPE color of the bractea of the peduncle, $L I N$ inflorescence length $(\mathrm{cm}), D I N$ inflorescence diameter $(\mathrm{cm}), S Y L$ syncarp length after closure of the last flower $(\mathrm{cm}), S Y D$ syncarp diameter after closure of the last flower $(\mathrm{cm}), L C R$ crown length after closure of the last flower (cm), SSY shape of the syncarp at 30 days, $P B C$ presence of bractea under the crown, $C B C$ color of the bractea under the crown, $C S F$ color of the syncarp after closure of the last flower, $C S D$ color of the syncarp at 30 days, $A B S$ absent, $B U R$ burgundy, $C O N$ conical, $C R E$ creamy white, $C Y L$ cylindrical, $D G R$ dark green, $D P I$ dark pink, $D P U$ dark purple, DRE dark red, ERE erect, GLO globose, $L G R$ light green, $L P I$ light pink, $L P U$ light purple, $L R E$ light red, MSI highly sinuous, ORA orange, $O V O$ ovoid, PRE present, $L S I$ little sinuous, TRA trapezoid with wide base, $Y E L$ yellowish

ananassoides or A. comosus var. parguasensis, although they do not meet certain conditions which are peculiar to these varieties. They may be natural hybrids among these varieties, but only further studies can corroborate this hypothesis.

The accession GPS-389 (AGB 195) is globoid, with small syncarp $(3.47 \mathrm{~cm}$ in length and $3.90 \mathrm{~cm}$ in diameter) and characteristics similar to those of A. comosus var. parguasensis (Table 5). This accession has potential to be used as minifruits or for landscape plants (Fig. 3e).

The accession FRF-202 (AGB 197) is the most differentiated among those evaluated from the germplasm active bank because its habit is different from all the three found on the list of morphological descriptors for pineapple. The leaves are small $(35.00 \mathrm{~cm})$, green, with wavy margins and small spines (Table 4). The inflorescences and syncarps are light pink and small (Table 5). This accession can be used in landscape plants, due to its unusual type of growth that forms massive and its high tillering. Due to the beauty of its fruits and absence of peduncle, its use as minifruits may be interesting (Fig. 3f).

The group $\mathrm{G} 7$ is formed by accessions of A. comosus var. bracteatus, accessions of the species A. macrodontes, one accession of A. comosus var. comosus, GF-492 (AGB 772) and one accession Ananas sp. G-69 (AGB 507).

The A. comosus var. bracteatus, also known as ananás-de-cerca, ananás selvagem, ananás-do-mato and karaguata-ruha, is mainly distributed in the southern Brazil, Northern Argentina and Paraguay.
It was observed that all of the accessions evaluated in this group were larger than $125.00 \mathrm{~cm}$, presenting normal growth habit and vigorous plants, forming large clumps, due to the abundant tillering. They are used as hedge in some regions, mainly because of the presence of large and aggressive spines along their leaves (Coppens D'Eeckenbrugge and Duval 2009).

The variation found is related to the color of the leaves and color, size and shape of the syncarp. Ananás Tricolor (AGB 17) has green leaves, white margins and pink spines (Fig. 3g). The accession Ananás vermelho do mato (AGB 03) presents darker leaves close to purplish red, with average size of $90.00 \mathrm{~cm}$ (Fig. 3k), while the other accessions presented green leaves with red spots.

In most accessions, the syncarp is dark pink, trapezoidal with wide base, measuring about $15.00 \mathrm{~cm}$, excepting the accession Ananás vermelho do mato, which is reddish, ovoid, measures $9.00 \mathrm{~cm}$ and is extremely ornamental.

The accession Silvestre 166 (AGB 97) has a light pink syncarp and is smaller $(7.10 \mathrm{~cm})$ than the other accessions of this variety.

The A. comosus var. bracteatus has accessions with thick peduncles and colorful syncarps. They are generally medium to large size, with juicy and edible pulp, whose flavor is not so appreciated as that of the other varieties cultivated for fresh consumption. There are records of its use in juices, in spite of the common presence of seeds (Coppens D'Eeckenbrugge and Duval 2009). 

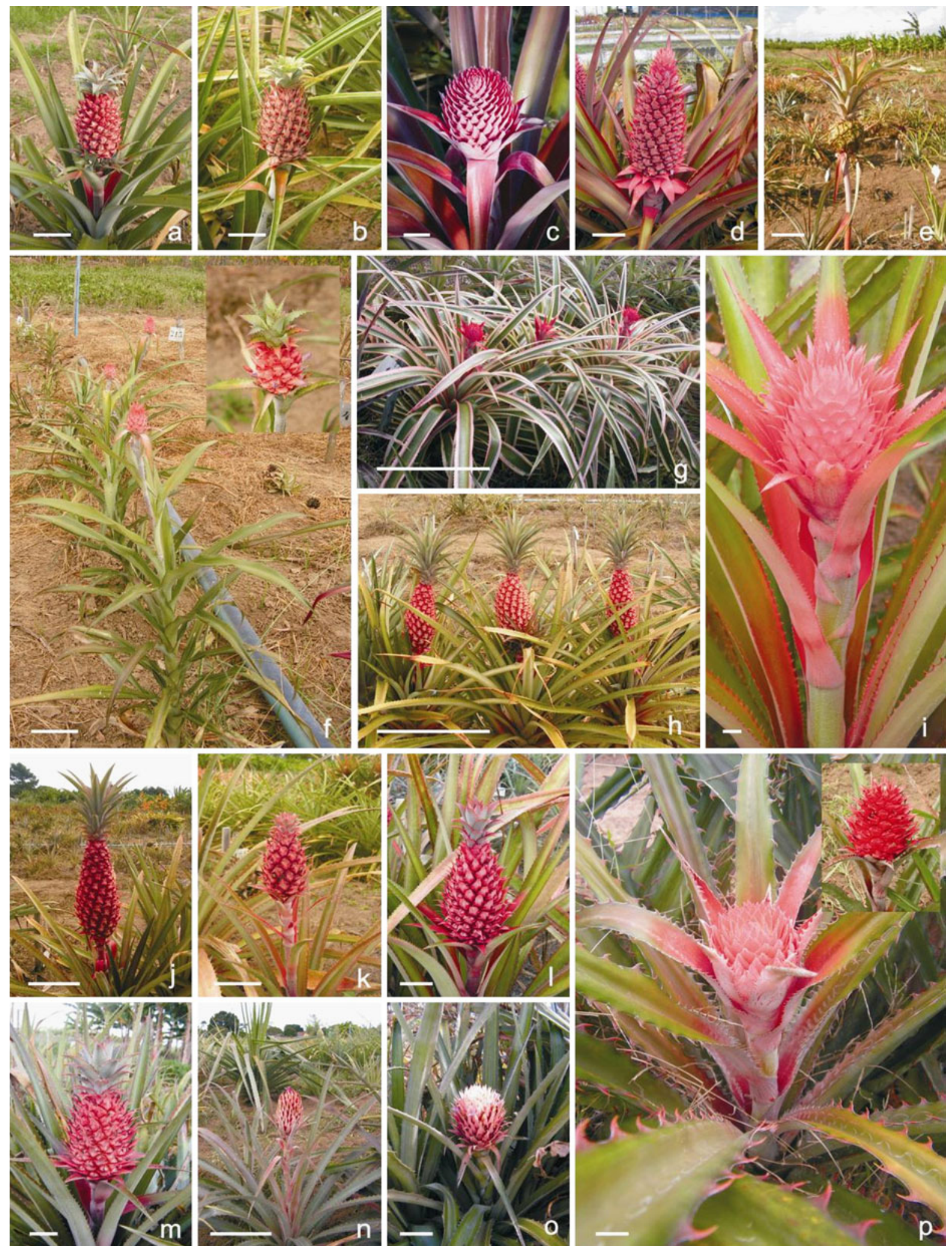
4Fig. 3 Genetic variation among pineapple trees with ornamental potential. a-d hybrids; a Ananás S. Bento $\times$ Local de Tefé (AGB 146), b Smooth Cayenne $\times$ Ananaí (AGB 148); c detail of the inflorescence, accession Pseudananas $\times$ Rondon (AGB 18); d Pseudananas $\times$ Rondon (AGB 18). e-f Ananas sp.; e GPS-389 (AGB 195); f FRF-202 (AGB 197). g-m A. comosus var. bracteatus; $\mathbf{g}$ detail of the inflorescence and leaves, accession Ananás Tricolor (AGB 17); $\mathbf{h}$ detail of the syncarps, accession FRF-1213 (AGB 543); i bud, accession FRF-16A (AGB 119); $\mathbf{j}$ detail of the cylindrical syncarp, accession FRF1213 (AGB 543); k Ananás Vermelho do Mato (AGB 03); l BGA-12 (AGB 56); m Selvagem 5 (AGB 47). n-p A. macrodontes; n I-26 803 (AGB 83); o FRF-327 (AGB 299); $\mathbf{p}$ detail of the inflorescence and leaves, with the presence of spines, accession Silvestre 25 (AGB 81). Bar $=1.00 \mathrm{~cm}$

In Northeastern Brazil, these pineapples, better known as 'Gravatás', are used at Christmas season for table decoration, mainly in rural communities. They are commonly found in street markets during that season, at very low cost, in spite of their beauty and durability.

Its use as ornamental plant is incipient in Brazil, but in other parts of the world it has been cultivated and marketed for this purpose.

Out of the 25 accessions of the A. comosus var. bracteatus evaluated in this study, only four presented variation, which demonstrates the need for molecular studies for the characterization of the other accessions and probable identification of duplicates. Duval et al. (2000, 2001b) reported that this variety presents little variation, due to its very narrow genetic base.

The species A. macrodontes, known as Pseudananas sagenarius in the former classification, has genotypes popularly known as gravatá-de-rede, gravatá-de-cerca-brava, nana-cabaça and yvira. It is a rustic, exuberant and vigorous plant that can reach 2.00 meters of height (Coppens D'Eeckenbrugge and Duval 2009). Outstanding characteristics in the species are the absence of crown and its propagation, by stretching below ground by means of stolons. For the four accessions evaluated, the maxiumm height achieved was $77.00 \mathrm{~cm}$, recorded in the accession FRF-1239 (AGB 719) (Table 4). The plants were not in their natural habitat, which may explain their reduced size.

The leaves are bowed, arranged in a rosette, with approximately $85.00 \mathrm{~cm}$ in length and $4.00 \mathrm{~cm}$ in width, coriaceous, with aggressive spines of the antrorse and retrorse type (Table 4). The lack of systematic cultivation of accessions of this species is the greatest hindrance for its exploration as ornamental plant. Its aggressiveness complicates the management and the phytotechnical procedures necessary for the culture.

The stems are erect, considered short and thick, with average length of $28.00 \mathrm{~cm}$ and diameter of $2.00 \mathrm{~cm}$. The syncarps presented an average of $9.73 \mathrm{~cm}$ in length and $7.29 \mathrm{~cm}$ in diameter (Table 2). These data agree with the descriptions of this genus recorded by Leme and Siqueira Filho (2006).

The color, size and shape of the syncarps presented variation. The accession Silvestre 25 (AGB 81) has green leaves and pink spines, trapezoidal syncarp with wide base and intense red color. This accession of this species is the most indicated for ornamental pineapple breeding (Fig. 3p).

Another accession evaluated, I-26 803 (AGB 83), presents light pink ovoid syncarp, which can be observed in Fig. 3n.

There are records of the use of this variety for hedge, mainly due to the presence of spines distributed throughout the plants (Coppens D'Eeckenbrugge and Duval 2009).

Morphological characterization performed in this study allowed for some inferences on the pineapple taxonomy, considered one of the most complicated of the Bromeliaceae family, probably due to the agricultural profile of the genus. The current classification divides the genus in two species: Ananas comosus with five botanical varieties (A. comosus var. ananassoides, A. comosus var. bracteatus, A. comosus var. erectifolius, A. comosus var. parguasensis and $A$. comosus var. comosus) and A. macrodontes (Coppens D'Eeckenbrugge and Leal 2003). The most significant difference in relation to the previous taxonomy refers to the five botanical varieties which were earlier considered species (Smith and Downs 1979), ignoring the absence of incompatibility barriers between them, among other attributes required for this classification (Leal et al. 1998).

The seven groups formed in this study and the species distribution considering their site of origin adjusts better to the current taxonomy, and also considering previous results obtained by this research group where hybridizations were possible among all varieties of A. comosus (Souza 2010), including the interspecific hybridization with $A$. macrodontes and A. comosus var. comosus. 
Fig. 4 Location of accesses based on passport data showing the botanical variety (colorful circles) and grouping (number) achieved by the UPGMA method based on the Gower algorithm, from twenty-five qualitative and quantitative characters (1 G1 group; 2 G2 group; 3 G3 group; 4 G4 group; 5 G5 group; 6 G6 group; 7 G7 group). Brazilian states: AC Acre, $A L$ Alagoas, $A P$ Amapá, $A M$ Amazonas, $B A$ Bahia, $C E$ Ceará, $D F$ Distrito Federal, ES Espírito Santo, $G O$ Goiás, $M A$ Maranhão, $M T$ Mato Grosso, $M S$ Mato Grosso do Sul, $M G$ Minas Gerais, $P A$ Pará, $P B$ Paraíba, $P R$ Paraná, $P E$ Pernambuco, $P I$ Piauí, RJ Rio de Janeiro, $R N$ Rio Grande do Norte, $R S$ Rio Grande do Sul, $R O$ Rondônia, $R R$ Roraima, $S C$ Santa Catarina, SP São Paulo, SE Sergipe, TO Tocantins

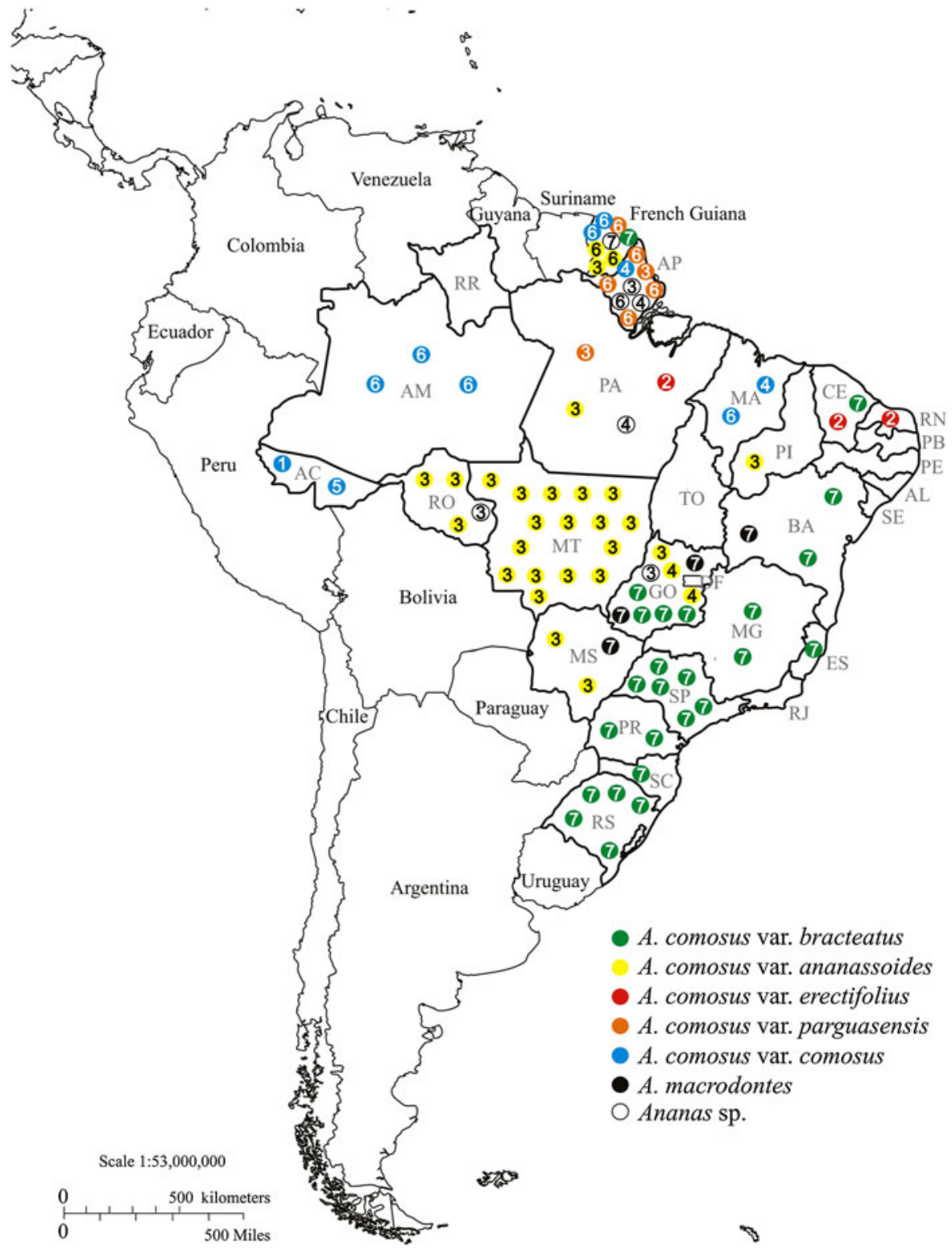

var. parguasensis and A. comosus var. bracteatus (representatives of G4, G6 and G7 groups) and A. comosus var. erectifolius $(\mathrm{G} 2)$, showing a greater variation of wild and cultivated forms than the variation found in the Western Central, Southern and Southeastern regions of Brazil, with most of them being A. comosus var. ananassoides (G3), A. comosus var. bracteatus and the species A. macrodontes (G7). According to these authors, the Southeastern region of Brazil could be a secondary center of origin of these species. This difference observed in the genetic 
variation between these two regions corroborate with the results obtained in the present work, reinforcing this theory.

On the other hand, the formation of groups G4 and G6 showed a morphological similarity among different accessions from different botanical varieties, with most of them in two groups, including some hybrids. The A. comosus var. ananassoides, which shows a wide range of morphological and adaptive variations from forest type to savannah, were concentrated basically on G3, but may be found in other groups with another botanical varieties, mainly with $A$. comosus var. comosus.

These two varieties show the highest genetic variation inside the genus, justifying their distribution in many regions in the country. The accession AGB 377 , included in this group as Ananas sp., is probably a A. comosus var. ananassoides since the passport data recorded its origin in the savannah where the occurrence of A. comosus var. parguasensis is not observed. The other accessions of Ananas sp. (AGB 393 and AGB 197) were originated from the Northern region, where A. comosus var. ananassoides and A. comosus var. parguasensis are present and, therefore, more studies are needed for their correct classification. The AGB 197 is the only accessions that does not hybridize with any other accession and, currently, several studies are ongoing to clarify this matter (Souza et al. 2011).

\section{Conclusions}

The pre-selected accessions from the pineapple AGB presented wide genetic variation and can be classified into different ornamental use categories;

The widest genetic variation observed inside the variety is recorded among the accessions of A. comosus var. ananassoides, which have striking characteristics for use as cut flower;

The A. comosus var. erectifolius form the group $\mathrm{G} 2$ and can be used for landscape plants, cut flower, pot plant and minifruits;

The accessions A. comosus var. bracteatus and A. macrodontes are selected for landscape plants and hedge;

Different accessions of the varieties studied can be used as parents in the genetic breeding program for the generation of pineapple ornamental hybrids.
Acknowledgments To the Banco do Nordeste S/A, for the financial support to the project, Fundação de Amparo à Pesquisa do Estado da Bahia (FAPESB) and Coordenação de Aperfeiçoamento de Pessoal de Nível Superior (CAPES) for the scholarships granted.

Open Access This article is distributed under the terms of the Creative Commons Attribution Noncommercial License which permits any noncommercial use, distribution, and reproduction in any medium, provided the original author(s) and source are credited.

\section{References}

Brainer MSCP, Oliveira AAP (2007) Floricultura: perfil da atividade no Nordeste Brasileiro. Banco do Nordeste, Fortaleza

Coppens D'Eeckenbrugge G, Duval MF (2009) The domestications of pineapple: context and hypotheses. Pineapple News 16:15-26

Coppens D'Eeckenbrugge G, Leal F (2003) Morphology, anatomy and taxonomy. In: Bartholomew DP, Paull RE, Rohrbach KG (eds) The pineapple: botany, production and uses. CABI Publishing, New York, pp 13-32

Cruz CD, Regazzi AJ (1997) Modelos biométricos aplicados ao melhoramento genético. Universidade Federal de Viçosa, Viçosa

Duval MF, Coppens D'Eeckenbrugge G, Ferreira FR, Cabral JRS, Bianchetti LB (1997) First results from joint Embrapa-Cirad Ananas germplasm collecting Brazil and French Guyana. Acta Hortic 425:137-144

Duval MF, Noyer JL, Hamon P, Coppens D’Eeckenbrugge G (2000) Study of variability in the Genus Ananas and Pseudananas using RFLP. Acta Hortic 529:123-131

Duval MF, Coppens D'Eeckenbrugge G, Fontaine A, Horry JP (2001a) Ornamental pineapple: perspective from clonal and hybrid breeding. Pineapple News 8:13-14

Duval MF, Noyer JL, Perrier X, Coppens D'Eeckenbrugge G, Hamon P (2001b) Molecular diversity in pineapple assessed by RFLP markers. Theo Appl Genet 102:83-90. doi: $10.1007 / \mathrm{s} 001220051621$

FAO, FAOSTAT (2011) Agricultural statistics database. Wold Agricultural Information Center, 2009 Rome. http://fao stat.fao.org/site/567/DesktopDefault.aspx ?PageID=567\# ancor. Cited 23 Mar 2011

Gower JC (1971) A general coefficient of similarity and some of its properties. Biometrics 27:857-874. doi:10.2307/2528 823

Harvey A (2000) Strategies for discovering drugs from previously unexplored natural products. Drug Discov Today 5:294-300. doi:10.1016/S1359-6446(00)01511-7

IBPGR (1991) Descriptors for pineapple. International Board for Plant Genetic Resources, Rome

Leal F, Amaya L (1991) The curagua (Ananas lucidus, Bromeliaceae) crop in Venezuela. Econ Bot 45:216-224. doi: 10.1007/BF02862049

Leal F, Antoni MG (1981) Espécies del género Ananas: origem y distribución geográfica. Revista de la Facultad de Agronomia 29:5-12 
Leal F, Coppens D’Eeckenbrugge G, Holst BK (1998) Taxonomy of the genera Ananas and Pseudananas: a historical review. Selbyana 19:227-235

Leão AL, Machado IS, Souza SF, Soriano L (2009) Production of curaua fibers for industrial applications: characterization and micropropagation. Acta Hortic 822:227-238

Leme EMC, Siqueira Filho JA (2006) Taxonomia das bromélias dos fragmentos de Mata Atlântica de Pernambuco e Alagoas. In: Siqueira Filho JA, Leme EMC (eds) Fragmentos de Mata Atlântica do Nordeste. Andrea Jakobsson Estúdio, Rio de Janeiro, pp 190-381

Manetti LM, Delaporte RH, Laverde Junior A (2009) Metabólitos secundários da família Bromeliaceae. Quim Nova 32:1885-1897. doi:10.1590/S0100-40422009000700035

Marques G, Gutiérrez A, Del Rio JC (2007) Chemical characterization of lignin and lipophilic fractions from leaf fibers of curaua (Ananas erectifolius). J Agric Food Chem 55:1327-1336. doi:10.1021/jf062677x

Maurer HR (2001) Bromelain: biochemistry, pharmacology and medical use. CMLS Cell Mol Life Sci 58:1234-1245. doi: 10.1007/PL00000936

Mohanty A, Tripathy PC, Misra M, Parija S, Sahoo S (2000) Chemical modification of pineapple leaf fiber: graft copolymerization of acrylonitrile onto defatted pineapple leaf fibers. J Appl Polym Sci 77:3035-3043. doi: $10.1002 / 1097-4628$

R Development Core Team (2006) A language and environment for statistical computing. R Foundation for Statistical Computing, Vienna

Rohlf FJ, Fisher DR (1968) Tests for hierarchical structure in random data sets. Syst Zool 17:407-412

Sanewski GM (2009) Breeding Ananas for the cut-flower and garden markets. Acta Hortic 822:71-78

SAS Institute (2004) SAS/STAT 9.1 user's guide. SAS Institute, Inc, Cary, NC
Singh D (1981) The relative importance of characters affecting genetic divergence. Indian J Genet Plant Breed 41:237-245

Smith LB, Downs RJ (1979) Bromelioideae (Bromeliaceae). Flor Neotropica Monogr 14:1493-2141

Sokal RR, Rohlf FJ (1962) The comparison of dendrograms by objective methods. Taxon 11:33-40

Souza EH (2010) Pré-melhoramento e avaliação de híbridos de abacaxi e banana para fins ornamentais. Dissertação (Mestrado): Centro de Ciências Agrárias, Ambientais e Biológicas, Universidade Federal do Recôncavo da Bahia. $156 \mathrm{p}$

Souza EH, Souza FVD, Costa DS Jr, Rossi ML, Soares TL, Martinelli AP (2011) Morfoanatomia polínica e fertilidade de Ananas sp. (BAG 197) com potencial ornamental. In: $6^{\circ}$ Congresso Brasileiro de Melhoramento de Plantas, 2011, Panorama Atual e Perspectivas do Melhoramento de Plantas no Brasil, Armação dos Búzios 6:4030

Souza FVD, Cabral JRS, Cardoso JL, Benjamin DA (2006) Identification and selection of ornamental pineapple plants. Acta Hortic 702:93-99

Souza FVD, Cabral JRS, Souza EH, Santos ON, Santos-Serejo JA, Ferreira FR (2007) Caracterização morfológica de abacaxizeiros ornamentais. Magistra 19:319-325

Souza FVD, Cabral JRS, Souza EH, Ferreira FR, Nepomuceno OS, Silva MJ (2009) Evaluation of F1 hybrids between Ananas comosus var. ananassoides and Ananas comosus var. erectifolius. Acta Hortic 822:79-84

Tamura K, Dudley J, Nei M, Kumar S (2007) MEGA4: molecular evolutionary genetics analysis (MEGA) software version 4.0. Mol Biol Evol 24:1596-1599. doi: 10.1093/molbev/msm092

Zah R, Hischier R, Leão AL, Braun I (2007) Curauá fibers in the automobile industry - a sustainability assessment. J Clean Prod 15:1032-1040. doi:10.1016/j.jclepro.2006.05.036 